\title{
Osmanlılarda Kütüphane Kültürü ve Bilimsel Yaşama Etkisi*
}

\section{Library Culture in Ottomans and Its Effect on Scientific Life}

\author{
Hakan Anameriç*
}

Özet

Osmanl Devleti içerisinde önemli vakerf kurumlarnndan olan kütüphaneler, yaklassı 800 yulder Anadolu topraklarnda Türk kültür, bilim, eğitim ve sanat yașam içerisinde bulunan sosyal kurumlardr. Bu u₹un süreç boyunca kütüphaneler, ceșitli dönemlerde toplumun cessitli simflarna bilginin aktarlmasinda, üretilen bilgi kaynaklarmm korunmasinda, çoğaltılmasinda ve bizmete sunulmasinda aktif olarak görev almuşlardır. Birçok bükeümdar, üst düzey devlet yöneticisi, bilim ve din adam bu kurumlarn olusturulmasinda, hizmet ve dermelerinin gelistirilmesinde önemli katkilarda bulunmuştur. Bu bağlamda, bir kütüphanede verilen biəzmetlerin neler olacağg, çalşanlarn görev ve sorumluluklar kütüphanelere ilişkin birçok vakfigyede en ince ayrntısina kadar açlklanmıştr. Osmanl Devleti döneminde kurulan kütüphanelerin dermeleri, mimari özellikleri, çalssanlar, bukuki düzenlemeleri, bizmetleri ve ünlü bilim

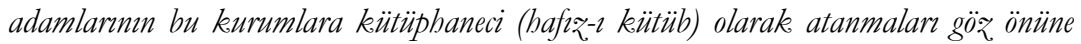
alındiğnnda, bu kurumlarn Osmanl medeniyetince biçbir dönem göz ardv edilmediği bir gerçektir. Kütüphaneler, XV. yü̈ynldan itibaren Osmanl eğitim-ögretim ve bilimsel yaşamma önemli katkılar yapmıs kurumlar olarak karşımız̧a şıkmaktadı. Ancak Osmanl Devleti'nin XVII. yüzynldan itibaren askeri, siyasi ve ekonomik sorunlar nedeniyle zaynflamasi ile birlikte, bu kurumlarn da toplumun bilimsel, kültü̈rel ve sosyal yașamı üzerindeki etkisi az̧almaya başlamıstır.

Abstract

Libraries, established as foundation, were very important service institutions in the Otoman Empire. These foundations contributed to social, cultural, scientific and educational life development of Anatolia nearly 800 years. During these times libraries played important role in collecting, protecting, serving and disseminating of information and knowledge to the society. Many sultans, sultanas, princes, princesses and statemen actively took part in the initiation and development of these vitally important foundation. Foundations deeds enumerated types of services, responsibilities of library worker, and

\footnotetext{
* 25.11.2005 tarihinde VI. Uluslararası Türk Kültürü Kongresi'nde aynı adla sunulan bildirinin gözden geçirilmiş şeklidir.

* Arş. Gör., Ankara Üniversitesi Dil ve Tarih-Coğrafya Fakültesi Bilgi ve Belge Yönetimi Bölümü ögretimelemanı.E-posta: anameric@humanity.ankara.edu.tr
} 
other qualities related to libraries. A close examination shows that the collections of libraries, architectural characteristics, statys of employees, legal organization, services, and distincly appointment of famous scientists to these foundation as librarianshad always recieved attention and their importance never been neglected. However, after XVIIIth century, contribution of these foundations gradually lessened in terms of scientific, cultural, and social life as a result of military, economic, and social problems.

Anahtar kelimeler

Osmanl vakuf kütüphaneleri, kütüphanecilik, bilim ve kütüphaneler, Osmanlilarda eğitim, bilim kurumlar

Keywords

Ottoman foundation libraries, librarianship, science and libraries, education in Ottoman Empire, scientific institttions

Osmanlı Devleti, XIV. ve XX. yüzyıllar arasında geniş bir coğrafyaya yayılmış, bünyesinde çeşitli etnik ve dini kökenden vatandaşların ticari, sosyal, kültürel, dini ve bilimsel etkinliklerini sürdürdügü bir devletti. Bu nedenle Osmanlı Devleti'nde, geniş ve zengin bir kültür birikimi oluşmuştu ve bu durum var olan kültür birikiminin diğer nesillere aktarılmasını beraberinde getirmekteydi. Sözü edilen kültür kapsamı altında; Osmanlılarda ön planda olan bazı sanat dalları (musiki, minyatür, hat, vb.), tarih, felsefe, din, edebiyat, eğitim-öğretim, spor, yemek, törenler (ritüeller), giyim, bilim gibi toplumun gündelik yaşamını oluşturan ve eylemler sonucunda ortaya çıkan düşünsel ve eylemsel unsurlar yer almaktaydı. Yaşam süresince oluşan bu kültür unsurları, tarih boyunca yazılı veya sözlü olarak kuşaktan kuşağa aktarılmıştır. Osmanlılar da diğer büyük devletler gibi kültürünü çeşitli bilgi kayıt ortamlarına kaydederek korumuş ve kendisinden sonra gelen nesillere aktarmaya gayret etmiştir.

Kültür birikimi ve kuşaktan kuşağa aktarılması aynı zamanda bir bilgi birikimi ve aktarımıdır. Bilgi de kendi içerisinde üretilme ve elde edilme yöntemlerine göre farklılıklar göstermektedir. Dini bilgi, felsefi bilgi, sanat bilgisi, bilimsel bilgi ve mistik bilgi, sözü edilen türler olarak nitelendirilebilir. Bu bilgi türlerinin tümü ve bunlara ait aktarılma ve kullanılma özellikleri toplumun kültürünü meydana getirmektedir. Osmanlılarda çeşitli bilgi türlerinin yazılı olarak aktarılmasında çoğunlukla ferman, berat, ahidname vb. devlet yayınları, telif / tercüme kitap, risale, şerh, haşiye, hamiş ve minyatür kullanılmıştır. XIX. yüzyılın (1831) ikinci çeyreğinden itibaren ise; gazete ve dergi gibi süreli yayınlar, en fazla kullanılan bilgi kayıt ortamları ve iletişim araçları olmuştur. $\mathrm{Bu}$ 
bilgi kaynakları çeşitli dönemlerde -içinde bulunulan siyasi ortam ile bağlantılı olarak- farklı türlerde bilginin kaydedilmesinde ve aktarılmasında kullanılmıştır.

Ancak, bilginin yalnızca kayıt edilip korunması, bilginin doğasında olan "paylaşılabilir" olma özelliğine aykırıdır. $\mathrm{Bu}$ nedenle, kayıtlı bilginin, çeşitli alanlarda bilgi sahibi olmak ve araştırma yapmak isteyen kimselere, belirli kurallar çerçevesinde ve ücretsiz olarak sunulması gerekmektedir. $\mathrm{Bu}$ işlemi kurallar çerçevesinde gerçekleştirecek olan sosyal kurumlar kütüphanelerdir. Fakat kütüphaneler, kültür tarihimiz içerisindeki rolleri bakımından pek fazla ele alınmamıştır. Oysa kütüphanelerimizin, -Karahanlılar'dan Osmanlılar'a kadar- Anadolu üzerinde hüküm sürmüş devletlerin eğitim-öğretim, kültürel ve bilimsel yaşamında yaklaşık 1000 yıllık geçmişleri olan sosyal kurumlar olduğu bilinmektedir. Bunun yanı sıra kütüphaneler, Osmanlıların da dahil olduğu İslami eğitim-öğretim sisteminin de yakından ilgili olduğu bilimsel kurumlar içerisinde yer almaktadır. $\mathrm{Bu}$ eğitim-öğretim politikasının temel eğitim kurumları medreselerdir. Buradan hareketle kütüphaneleri de yukarıda belirttiğimiz gibi eğitim-öğretim kurumlarının parçası olarak ele aldığımızda Osmanlılarda da ilk kütüphanelerin bu kurumlar bünyesinde veya yakınlarında kurulmuş olması bir gerçektir.

Büyük Selçuklu Devleti'nin ünlü veziri Nizamü'l-Mülk tarafindan kurulan ve kendi adıyla anılan Nizamiye Medreseleri'ndeki eğitimöğretim metodu ile idari yapılanma şekli, Büyük Selçuklu Devleti'nden Anadolu Selçuklular'a ve oradan da Osmanlı Devleti'ne geçmiştir. Osmanlılar, kurulduğu günden itibaren ülkelerini zengin kütüphaneler ile donatmışlar ve İslam dünyasının çeşitli bölgelerinden bilim adamlarını o dönemin şartlarına göre oldukça cezb edici teklifler ve olanaklarla ülkelerine çekmişlerdir. Böylelikle sırasıyla İznik, Bursa, Edirne ve İstanbul değerli bilim adamlarının ve önemli eğitim-öğretim kurumlarının dolayısıyla da büyük kütüphanelerin bulunduğu merkezler haline gelmişlerdir. ${ }^{1}$

İslam uygarlığında kütüphaneler, "yabancı ilimlere yer veren kurumlar (akli bilimler)" içerisinde değerlendirilmektedir. Bu ayrımın kaynağı da İslam'ın temel eğitim kurumları olan mescid ve medreselerden kaynaklanmaktadır. Klasik İslam'da medrese, eğitim kurumlarının en önde gelenidir ve öncelikle İslami ilimlerin gözdesi olan fıkıh eğitimi için kurulmuştur. Medresenin içinde doğup geliştiği "mescid", fikıh da dahil olmak üzere İslami ilimlerin (nakli ilimler) farklı türlerinin eğitimi için kullanılmaya devam etmiştir. Medresenin bu

${ }^{1}$ Aykut Kazancigil, Osmanlilarda Bilim ve Teknoloji, İstanbul, 2000, s. 12. 
merkezi konumu nedeniyle, İslam'ın diğer eğitim kurumları, medrese öncesi ve medrese sonrası olmak üzere iki döneme ayrılmaktadır. İslam, İslami bilimler ile akli bilimleri birbirinden ayırdığı için, medrese öncesi dönemin kurumları da kendi içinde, akli bilimlere yer verenler ve vermeyenler biçiminde bir ayrıma tabi tutabilir. Akli bilimlere yer vermeyen medrese öncesi kurumlar, içinde ders halkaları bulunan camiler ve mescitlerdir. Akli bilimlere yer veren kurumlar ise; kütüphaneler ve hastanelerdir. ${ }^{2}$ İslam'ın temel eğitim kurumları olan ve akli bilimlere yer vermeyen medreselerde okutulan İslami bilimler içerisinde tefsir, hadis, fikıh ve kelam yer almakta; akli bilimlerde ise; Aristoteles'ten başlayarak temelde matematik, fizik, metafizik (nazari ilimler) ahlak, iktisat ve siyaset (ameli ilimler) yer almaktaydı. Bu bilimler, Antik Yunandan alınmış ve Osmanlı Devleti'nin kurulmasına değin İslam bilginleri tarafından çeşitli yönlerden ele alınarak geliştirilmiştir. Aritmetik, geometri, astronomi ve müzik gibi diğer matematik ve fizik ile ilgili bilimler de bunların altında yer almıştır. ${ }^{3} \mathrm{Bu}$ açıdan değerlendirildiğinde kütüphaneler nakli bilimler kadar akli bilimlere de yer veren eğitim kurumları olarak ön plana çıkmaktadır.

İslam uygarlığında kütüphaneleri tanımlamak amacıyla, bazı tamlamalar kullanılmaktaydı. Bu tamlamaları oluşturan kelimelerden üçü beyt, hizâne ve dâr gibi mekanı ifade eden kelimeler diğerleri ise; hikme(t), ilim ve kütüb gibi içeriği ifade eden kelimelerdir. Bu kelimelerden türeyen ve kütüphaneyi ifade eden terimler ise şu şekilde sıralanabilir; beytü'l-hikme, hizânetü'l-hikme, dârü'l-hikme, dârü'l-ilim, dârü'l-kütüb, hizânetü'l-kütüb, beytü'l-kütüb, beytü'l-ilim ve elhizânetü'l-ilmiyye. ${ }^{4}$ Büyük Selçuklular'da beytü'l-hikme, hizânetü'lkütüb, hızânetü'l-hikme, dârül-hikme, dârü'l-ilim ve dârü'l-kütüb adlarıyla kütüphaneler kurulmuştur. ${ }^{5}$ Kurulan bu kütüphaneler genellikle büyük şehirlerde cami, mescid, ribat, hankah ve medrese gibi eğitimibadet kurumlarında ve evler içerisinde yer almaktaydı. Bu kütüphanelerin dermelerinde hemen her türlü konuda kitap yer almaktaydı. Bu kütüphaneleri kuranlar (vâkıf) ilk dönemlerde kitaplarını yararlanmak isteyenler için vakfetmişler ve okuyucular için herhangi bir

${ }^{2}$ George Makdisi, Ortaçă̆’da Yüksek Öğretim: İslam Dünyası ve Hıristiyan Batı, Çeviren: Ali Hakan Çavuşoğlu ve Hasan Tuncay Başoğlu, İstanbul, 2004, s. 47-48.

${ }^{3}$ Remzi Demir, Osmanlilar'da Bilimsel Düşüncenin Yapısı, Ankara 2001, s. 46-47. ${ }^{4}$ Makdisi, a.g.e., 2003, s. 67-68.; Youssef Eche, Les Bibliothèques Arabes Publiques et Semi-Publiques en Mèsopotamie, Syrie et en Egypte au Moyen Age, Damascus, 1963, s. 305309.

5 Jonathan M. Bloom, Kağıda İslenen Uygarlı: Kağıdın Tarihi ve İslam Dünyasına Etteisi, Çeviren: Zülal Kılıç, İstanbul, 2003, s. 165-166. 
sınırlama yapmamışlardır. Hatta kalacak yeri, yeterli parası olmayanlara, konaklama, yiyecek-içecek ve para yardımları da yapılmaktaydı. Bunun yanı sıra kurulan kütüphaneler, medreselerde eğitim veren müderrisler ve öğrenim gören talebelere (talebe-i ulum) gereksinim duydukları kitapları sağlamaktaydılar. Kıraat ve istinsah gibi kitaplarla ilgili faaliyetlerin de yürütüldüğü kütüphanelerde ayrıca, müzakere ve münazara amaçlı toplantılar da düzenlenmekteydi.

Geçmişte de Türk kütüphaneleri ve kütüphaneciliğinin temel amac1, üretilen bilginin (bilgi kaynaklarının) korunması üzerine yoğunlaşmıştır. $\mathrm{Bu}$ temel amaç üzerine kurulan hizmetlerin diğer hedefleri ise; yine üretilmiş bilginin geleceğe iletimi ve bilginin kütüphaneler aracillğı̀la toplumsallaştırılması sağlamaktır. Soysal'ın da belirttiği üzere; "Olumsuz sayılabilecek kimi davranışlara karşın, anılan kimliğin, günün yazılı kültürün başlıca birikim merkezi ve yaygın bilgi iletişim aracı olarak kütüphanelere, toplumsal söyleşi ya da düşün alışverişini daha sağlıklı yoldan gerçekleştirme olanağı vermesi söz konusudur."

Osmanlı Devleti'nin çeşitli dönemlerinde dini, bilimsel ve edebiyat ile ilgili konularda kitap toplama ve kütüphane oluşturma, geleneksel bir hal almıştır. Osmanlı Devleti'nin kuruluş döneminden itibaren padişahlar, vezir-i azamlar, padişah hanımları, şehzadeler, darüssaade ağaları, defterdarlar, şeyhülislamlar ve diğer devlet görevlileri eğitim kurumları, ibadethaneler, külliyeler ve bu kurumların içerisinde ya da bağımsız binalara sahip kütüphaneler kurmuşlardır. Kurulan kütüphanelerin hemen hepsi vakıf kurumları olarak kurulmuş, amaçları, yönetimi, gelirgiderleri, personeli, personel özellikleri - sayıları ve dermeleri ile ilgili bilgiler de vakfiyelerinde yer almıştır.

$\mathrm{Bu}$ bağlamda, Osmanlı toplumu içerisinde saray mensupları ve ulemanın kütüphanelere dolayısıyla da yazılı kültüre olan ilgisi dikkat çekicidir. Ancak önemli olan nokta, bu sınıfların dışındaki ve çoğunluğu oluşturan tebaanın yazılı kültüre olan ilgisidir. Daha önce de belirtildiği gibi İznik, Bursa, Edirne ve İstanbul gibi Osmanlı Devleti'ne çeşitli dönemlerde başkentlik yapmış merkezlerin dışında bu ilgi pek fazla gelişmiş değildi. Kütüphanelerin ortaya çıkış nedenleri ve içinde bulundukları kurumlar da göz önüne alınırsa, bu durumun kaçınılmaz olduğu da bir gerçektir.

Osmanlı Devleti'nde kuruluşundan yıkılışına kadar geçen dönem içerisinde bina ve yerleşim özelliklerine göre farklı özelliklerde

6 Özer Soysal, Türk Kütüphaneciliğ - I: Geleneksel Yapıdan Yeniden Yapılanısa, Ankara, 1998, s. 23. 
kütüphaneler kurulmuştur. Sözü edilen kütüphaneler şu 5 ana tür altında toplanabilir:

- Padişahların şehzadelik ve hükümdarlık dönemlerinde, bulundukları saraylarda kurulmuş özel (kişisel) kütüphaneler,

- Evler, konaklar, odalar vb. yerlerde kişisel amaçla kurulmuş kütüphaneler.

- Cami, medrese, mektep ve dersane gibi çeşitli eğitim-öğretim kurumları içerisinde ya da bu kurumların yakın çevrelerinde kurulmuş kütüphaneler,

- Tekke, zaviye, türbe, hankah, ribat, mescit, dergâh ve mevlevihane gibi eğitim-ibadet kurumları içerisinde ya da çevresinde kurulan kütüphaneler,

- Kendine özgü, bağımsız (müstakil) binaya sahip kütüphaneler, ${ }^{7}$

$\mathrm{Bu}$ şekilde kurulan kütüphanelerde bulunan dermelerin oluşturulması büyük oranda vakfedilen kitaplarla gerçekleştirilmiştir. Ancak oluşturulan bu derme aynı miktarda kalmamış ve zaman içerisinde çeşitli yollarla gelişme göstermiştir. Kuruluş döneminden itibaren Osmanlı kütüphaneleri dermelerini şu yollarla genişletmişlerdir:

- Vakıf sahiplerinin çeşitli dönemlerde vakfettiği kitaplar,

- Çeşitli kimselerin vakfettiği kitaplar,

- Satın alma ile sağlanan kitaplar,

- Kitap yazdırma - çoğaltma (katiban-ı kütüblerin ${ }^{8}$ istinsah ettikleri kitaplar),

- Çeşitli hükümdar, elçi, devlet adamları ve ileri gelenlerden gelen hediye kitaplar,

- Müsadere ile sağlanan kitaplar,

- Ganimet yoluyla sağlanan kitaplar. ${ }^{9}$

7 Özer Soysal, Türk Kütüphaneciliği - II: Belgeler Kütüphane Türleri, Görevlendirme İlkeleri, Ankara, 1998, s. 9, 205, 261, 311, 337.; Muzaffer Gökman, İstanbul Kütüphaneleri ve Bugünkü Durumlar, İstanbul 1939, s. 6-8.; İsmail E. Erünsal, "Osmanlı Kütüphanelerinin Tarihi Gelişimi”, Osmanl Devleti’nde Bilim, Kültür ve Kütüphaneler içinde (235-246). Yay. Haz: Özlem Bayram [ve diğerleri], Ankara, 1999, s. 235-242.; Şemim Emsen, Osmanlı İmparatorluğu Devrinde Türkiye Kütüphaneleri Tarihi, Türk Kütüphaneciler Derneği Bülteni, 9, (1-2), 1960, s. 18-19.

${ }^{8}$ Sarayda kitap çoğaltma ile görevli kimse. 
Osmanlılarda kütüphane ve kütüphaneciliğin gelişiminde, medreseler bünyesinde kurulan ve eğitim-öğretim faaliyetlerinin bir parçası olan kütüphanelerin yanı sıra, padişahların kendilerine ait saray kütüphanelerinin de önemli payı vardır. Osmanlı Devleti'nden önce Anadolu üzerinde kurulan diğer tüm Türk devletlerinde olduğu gibi Osmanlı hükümdarlarının da hemen tümünde kitap toplama ve bunları kullanma alışkanlığı vardı. Osman Gazi'den VI. Mehmet Vahdettin'e kadar olan tüm Osmanlı padişahlarının kendilerine ait en az bir kütüphaneleri vardı. I. Murat tarafından Bursa'da kurulmuş olduğu ifade edilen kütüphane, ilk saray kütüphanesi olarak nitelendirilmesi açısından önemlidir. ${ }^{10}$ I. Murat'ın yanı sıra Osmanlı kütüphane kültüründeki diğer önemli padişahlar II. Murat, Fatih Sultan Mehmet, II. Bayezit, Yavuz Sultan Selim, Kanuni Sultan Süleyman, III. Mehmet, I. Mahmut, I. Abdülhamit, III. Ahmet, III. Selim, Abdülaziz ve II. Abdülhamit olarak siralanabilir. Osmanlı Devleti'nde kurulan kütüphaneler yukarıda belirtilen temel grupların dışında, özellikle XVIII. yüzyılın sonundan itibaren ortaya çıkan batılılaşma ve çağdaşlaşma hareketlerine paralel olarak gelişen üniversite kütüphaneleri (darülfünun, hendesehane, mühendishane, mualimhane) ve çeşitli bilim dallarında kurulmuş dernekler (cemiyet) bünyesinde açılmış kütüphaneler olarak da ele almak gerekmektedir.

Osmanlı Devleti'nin kuruluş döneminde savaşlar, taht çekişmeleri, ekonomik ve siyasi yapının oturtulması için yapılan mücadeleler ve devlet birliğinin tamamlanması için yapılan çalışmalar nedeniyle eğitim, bilim ve kültür konularıyla dolayısıyla da kütüphaneler ile yeterince ilgilenilememiştir. Orhan Bey döneminde medreselerin kurulmaya başlamasıyla Osmanlı eğitim-öğretim sisteminde de önemli gelişmeler yaşanmıştır. Genişleyen sınırlar, artan idari memur gereksinimi ve devletin kurumsallaşma çalışmaları, çok sayıda medresenin açılmasına, öğretim görevlilerinin bu medreselerde görev yapmaları için dönemin önemli bilim ve kültür merkezlerinde eğitim görerek ülkelerine

9 Bu konudaki önemli olaylardan biri, Kanuni Sultan Süleyman'ın 1526'daki Budin Seferi ve 1541'deki seferler sonucunda ünlü Macar Kralı Matthias Corvinus'a (14581490) ait kütüphaneden (Bibliotheca Corviniana - Korvina Könyvtár) bazı kitapların savaş ganimeti olarak alınarak İstanbul'a getirilmesidir. Bu kitapların 35 tanesi 1877'de II. Abdülhamit tarafindan Avusturya-Macaristan İmparatorluğu'na geri verilmiştir. Bu konu için bkz. "Korvina", Révai Nagy Lexikon, Az. Ismeretek Enciklópédiá, c. 12., Budapest, 1915, s. 62-64.; "Corvina Könytár", Magyar Nagy Lexikon, Edi: László Élesztös, c. 5., Budapest, 1997, s. 620-621.

10 A. Süheyl Ünver, İkinci Selim'e Kadar Osmanlı Hükümdarlarının Hususî Kütüphaneleri Hakkında, IV. Türk Tarih Kongresi 10-14 Kasım Ankara içinde (294312), Ankara, 1952, s. 298. 
dönmelerine, dolayısıyla da buralardan getirmiş oldukları ve kendilerinin yazdıkları eserlerden küçük dermelerin oluşmasına neden olmuştur. $\mathrm{Bu}$ durum, ilerleyen dönemlerde kütüphaneleri medrese ve diğer eğitim kurumlarının vazgeçilmez bir parçası haline getirmiştir. Bu noktadan hareketle, Osmanlı Devleti 'nde bilinen ilk medrese kütüphanesi, Bursa'da Yıldırım Bayezit döneminde yaptırılan İnebey Medresesi bünyesinde kurulan ve ayrı bir oda halinde kullanılan kütüphanedir. ${ }^{11}$ Bunun yanı sıra Osman Gazi ve Orhan Gazi'nin kendilerine ait birer kitaplığı olduğu ve kendi dönemlerinde İznik ve Bursa'da kurulan medreselerde kütüphaneler kurulmuş olduğu bazı kaynaklarda ifade edilmektedir, ancak bu bilgiler tam ve kesin değildir. ${ }^{12}$ Özellikle I. Murat Hüdavendigar döneminden itibaren kurulan medreselerde kütüphanelere daha sık yer verilmeye başlamıştır.

Fatih Sultan Mehmet kendine ait ilk kütüphaneyi tarihi tam olarak belirlenemeyen ancak XV. yüzyılın ilk yarısı sonları olarak (1447-1449) tahmin edilen dönemde, Manisa'da Saruhan sancakbeyliği sırasında Şehzadeler Sarayı'nda kurmuştur. Kütüphanenin sonradan yanıp yıkılan, kısmen restore edilip bugünkü Manisa Halkevi'nde bulunan kulede kurulduğu tahmin edilmektedir. Fatih'in bu devre ait kitaplarının üzerinde "Mehmed bin Murad Han" mührü yer almaktadır. Fatih ikinci özel kütüphanesini, 1454'te kısmen Manisa'dan götürdüğü kitaplarla Edirne'deki Cihannüma Kasrı'nda kurmuştur. Bir diğer kütüphaneyi İstanbul'un fethinden hemen sonra bugünkü Bayezid Meydanı yakınlarında inşa edilen Eski Saray'da kurmuş, daha sonraki yıllarda bu kütüphane Topkapı Sarayı olarak bilinen Yeni Saray'a taşınmıştır. Bu dönemde Fatih'in kütüphanecisi filozof, matematikçi, bibliyograf ve şair olan Molla Lütfi'dir. Sinan Paşa'nın (Hoca Paşa), Molla Lütfi için Fatih'e "İme vakıftır. Elif gibi doğrudur. Kabiliyetlidir. Kütüphanenizi ona bırakını" diye öneride bulunduğu bilinmektedir. Fatih Sultan Mehmet, Hoca Paşa ve Molla Lütfi saraydaki kütüphanede bir araya gelerek

11 İsmail E. Erünsal, Türk Kütüphaneleri Taribi - II: Kuruluşundan Tanzimat'a Kadar Osmanl Vakıf Kütüphaneleri, Ankara, 1991, s. 6-7.; Ekrem Hakk1 Ayverdi, Osmanl Mimarisinin Illk Devri - I, İstanbul, 1966, s. 444. Fatih Rukancı and Hakan Anameriç, Libraries as Scientific, Educational and Cultural Institutions in the Otoman Empire (XIVth-XVIIth Centuries), Libri, 56 (4), 2006, s. 253.

$12 \mathrm{Bu}$ konuda bkz. Necmeddin Sefercioğlu, Osmanlı Döneminde Kütüphane Katalogları, Osmanl Devletinde Bilim, Kültür ve Kütüphaneler içinde (143-152), Ankara, 1999, s. 144.; Bedi N. Şehsuvaroğlu, Tarihte ve Bizde Kütüphane, Türk Kütüphaneciler Derneği Bülteni, 27 (1), 1978, s. 7-9.; Erünsal, a.g.m., 1999. s. 253. 
çalışmışlar, kütüphaneyi adeta bir akademi gibi kullanmışlardır. ${ }^{13}$ Fatih Sultan Mehmet döneminde kendi kurduğu saray kütüphanelerinin dışında ülkenin çeşitli şehirlerinde yaptırılan külliye, cami, medrese gibi eğitimöğretim kurumları içerisinde de çok sayıda kütüphane kurulmuştur. Kendisinin kurdurduğu Fatih Camii ve Külliyesi bunun en önemli örneklerinden biridir. ${ }^{14}$

Fatih dönemi, kütüphane kültürü açısından oldukça önemli ve diğer dönemlere nazaran daha parlak bir dönemdir. Bunun önemli nedenlerinden ilki 1453 yllında İstanbul'un fethedilmesi ile Fatih'in İstanbul'u devletin başkenti yapma isteğinin yanı sıra bu büyük devlete başkentlik yapacak olan şehri aynı zamanda dünyanın -özellikle de İslam dünyasının- en büyük sanat, bilim ve kültür merkezi yapma amacıdır. İstanbul'un fethi aynı zamanda Osmanlı Devleti'nin yükseliş dönemine girdiği süreci de ifade etmektedir. İkincisi, Fatih'in kişisel olarak bilim ve tekniğe olan ilgisidir. $\mathrm{Bu}$ da dolayısıyla ilgi alanına giren konularda gerekli olan yazılı belgeleri yakından takip ettiğini ortaya koymaktadır. $\mathrm{Bu}$ özel ilginin oluşmasında, birer bilim adamı olan hocaları Molla Güranî ve Molla Hüsrev'in de payı büyüktür. Üçüncüsü ise, Fatih'in kendisinden önce gelen padişahlardan da devraldığı konu bakımından geniş ve niceliksel olarak büyük sayıdaki kaynağa sahip olmasıdır.

II. Bayezit, Fatih Sultan Mehmet'in ölümüyle değerli bir kitap koleksiyonun da sahibi olmuştur. II. Beyazıt'ın kişisel olarak kütüphane kurma veya kurdurtma girişiminin yanı sıra kendisine ait kütüphanesini zenginleştirme ve koruma girişimleri ön plana çıkmaktadır. 1503-1512 tarihleri arasında II. Bayezit'in verdiği inam ve ihsanları tespit eden bir defterde, çeşitli vesilelerle verilen hediyelerin yanında padişaha kitap getirip karşıllığında ihsan alan çok sayıda kişiden de bahsedilir. Bu durum II. Bayezit'in kitap biriktirmeye olan büyük ilgisinin de bir göstergesidir. II. Bayezit, çeşitli yollarla kendisine ulaşan kitapların baş ve son sayfalarına kendi mührünü bastırmış, kitapların zahriyelerine ${ }^{15}$ kendi el yazısıyla isimlerini yazmıştır. ${ }^{16}$ Kendi kütüphanesinde çeşitli bilimlere ait

13 Müjgan Cunbur, Fatih'in Kurduğu Kütüphaneler, Önasya, 4 (45), 1969, s. 6.; Hakkı Şinasi Çoruh,. Fatih'in Kütüphane Memuru, Büyük Türk Ansiklopedisti Molla Lütfi ( - ?/1494), Türk Kültürü, 10 (115), 1972, s. 436.

14 Melek Dosay Gökdoğan ve Yavuz Unat, Fatih Dönemi (1451-1481) Bilim Anlayışı ve Bilim Adamları, İstanbul'un Fetbinin 550. Yıl An Kitabı içinde (35-46). Edi: Esin Kahya ve Ayten Aydin, Ankara, 2004, s. 35, 37.

${ }^{15}$ Kitabin sirtı veya arka kism1.

16 Ünver, a.g.m., 1952, s. 308-309.; Erünsal, a.g.e., 1999, s. 238.; Şehsuvaroğlu, a.g.m., 1978, s. 5. 
kitapları olan II. Bayezit, Fatih Sultan Mehmet'ten sonra en fazla kitaba sahip olan padişahtır.

Yavuz Sultan Selim döneminde kütüphane ve kütüphanecilikle ile ilgili gelenek Fatih Sultan. Mehmet dönemi ile paralellik göstermektedir. Yavuz Sultan Selim'in kitapları üzerindeki temellük kaydında "Selim Sah" ya da "Sultan Selim Sah" ibareleri bulunmaktadır. Yavuz Sultan Selim döneminde kütüphaneler ile ilgili olarak dikkat çekici olan nokta, 1514-1517 yılları arasında Doğu Anadolu, Suriye ve Misır'a yapılan seferlerdir. Bu seferler ile Osmanlı Devleti'nin sinırları Arabistan, Misır ve İran'a kadar genișlemiş ve Dulkadiroğlu Beyliği'nin de sona ermesiyle Anadolu Birliği, Yıldırım Bayezit’ten sonra tekrar sağlanmıştır. Bunun yanı sıra bu seferler, geçmiş dönemlerde bilim, kültür, sanat ve eğitim alanlarında önemli merkezler olan Urfa, Kahire, İskenderiye, Halep, Kudüs, Şam gibi kentlerin de ele geçirilmesine neden olmuş, bu kentlerdeki kültür ve sanat eserleri İstanbul'a gönderilmiştir. Sözü edilen merkezlerde bulunan kütüphanelerden alınan kitaplar, Yavuz Sultan Selim'in yapılan seferler sonucu kurduğu saray kütüphanesinin dermesini oluşturmuştur. ${ }^{17}$

Kanuni Sultan Süleyman döneminde sarayda kurulan kütüphanelerden çok, medrese ve külliyelerde kurulan kütüphanelerin ön planda olduğu görülmektedir. $\mathrm{Bu}$ dönemde nicelik bakımından diğer dönemlere nazaran önemli bir artış söz konusudur. Bunun en büyük nedeni "vakıf" kurumunun, devletin içerisinde bulunduğu ekonomik ve sosyal yönlerden en üst seviyeye çıkmasıyla büyük gelişim göstermiş olmasıdır. Ayrıca devlet; askeri, siyasi, adli, bilimsel ve kültürel yönlerden de en parlak dönem içine girmiştir. Kanuni Sultan Süleyman devleti en üst seviyeye çıkarmasının yanı sıra Osmanlı eğitim-öğretim sistemindeki büyük girişimlerinden birini de gerçekleștirmiştir. ${ }^{18} \mathrm{Bu}$

${ }^{17}$ Erünsal, a.g.e., 1991, s. 38-40, 44.

18 Osmanlı Devleti'nin temel eğitim kurumları olan medreselerin, I. Mehmed (Fatih) zamanında kurulan Sahn-1 Seman Medreseleri (nakli bilimler ağırlıkta) ile gerçek anlamda teşkilatlandırılmasının ardından, I. Süleyman (Kanuni) döneminde kurulan ve Osmanlı Devleti'nin ikinci büyük eğitim kurumu olan Süleymaniye Medreseleri (Sahn-1 Süleymaniye, Medaris-i Süleymaniye) açmış olduğu farklı bilim dalları nedeniyle (özellikle tıp, matematik ve diğer akli bilimler) yeniden bir sınıflamaya gidilmiştir. Kanunî döneminde yapılan düzenlemeyle Osmanlı medreselerinde eğitim Dahil medreselerinden sonra iki aşamaya ayrılmıştır. Birincisi Sahn-1 Seman medreselerinde hukuk, ilâhiyat ve edebiyat dallarında yapılan eğitim, ikincisi ise Süleymaniye medreselerinde matematik ve tıp alanlarında yapılan eğitimdir. $\mathrm{Bu}$ konuda ayrıca bkz. Ersoy Taşdemirci, Osmanlı İmparatorluğu'nda Medreseler, Erciyes Üniversitesi Sosyal Bilimler Enstitüiü Dergisi, (3), 1989, s. 523-526.; İsmail Hakk1 Uzunçarşılı, Osmanlı Devletinde İlmiye Teşkilatı, Ankara, 1965, s. 24-37. Halil İnalcık, 
girişim, eğitim-öğretim kurumlarının ayrılmaz parçaları halini alan kütüphaneler için de önemli dönem olmuştur.

II. Selim döneminde, Kanuni Sultan Süleyman'dan kalan güçlü bir devlet; ekonomik, sosyal ve bilimsel yönden oldukça ilerlemiş bir toplum yapısı miras alınmıştır. $\mathrm{Bu}$ yapının oluşmasında ve sürdürülmesinde Kanuni Sultan Süleyman kadar dönemin sadrazamı Sokollu Mehmet Paşa'nın da rolü büyüktür. II. Selim dönemiyle birlikte kütüphanelerin de mimari yapıları ve bulundukları mekanlar farklılaşmaya ve çeşitlenmeye başlamıştır. Artık; medrese, cami ve tekkelerin yanı sıra, evlerde kişisel ilgi alanlarına yönelik özel kütüphaneler, rasathanelerde araştırmalarla ilgili eserlerin yer aldığ 1 kütüphaneler kurulmaya başlamıştır. $\mathrm{Bu}$ dönemde diğer eğitim-öğretim ve ibadet kurumları içerisinde kurulan kütüphanelerden farklı Osmanlı Devleti'nde kurulan ilk rasathane kütüphanesi olarak adlandırabileceğimiz, ünlü gök bilimci Takiyyûddin Mehmet tarafından İstanbul'da kurmuş olduğu ve "Darü'r-rasadü'l cedid" adıyla bilinen rasathanenin kütüphanesidir. ${ }^{19}$

III. Murat da kitaplara özel ilgi duyan padişahlardan biriydi. III. Murat'a hediye edilenler arasında kitaplar da yer almaktaydı. 1589 yılında İran Şahı I. Abbas'ın elçisi olan Haydar Mirza, Şahın barış dileğini sunmaya geldiğinde, getirdiği hediyeler arasında özenle yazılmış ve ciltlenmiş Kur'an-1 Kerim'lerin yanı sıra Şahname, Hamse-i Nizamî, Külliyât-1 Hâkânî, Yusuf ü Züleyhâ, Hafiz Dîvânı, Mahzenü'l-esrâr, Rubaiyyat-i Hayyam ve Cemşid ü Hûrşid gibi İran klasikleri de bulunmaktayd $1 .{ }^{20}$ III. Murat dönemi Osmanlı Devleti'nin İran, Avusturya ve Venedik ile uzun savaşlar sonucunda ekonomik açıdan zayıflamaya başladığı bir dönemi de ifade etmektedir. Savaşlar sonucunda ekonomik yapının bozulması, para değerinin düşmesi, hayat pahalılığının artması gibi nedenler ülke içersinde huzursuzluğun yaygınlaşması ve isyanların meydana gelmesini de beraberinde getirmiştir. $\mathrm{Bu}$ olumsuz durumun XVII. yüzyılın başlarına kadar artarak devam etmesi, hayır kurumlarının kurulması ve işletilmesinde de önemli sorunların çıkmasına neden olmuştur.

Osmanl Imparatorluğu Klasike Çăg (1300-1600), Çeviren: Ruşen Sezer, İstanbul, 2003, s. 175-178.; Murat Akgündüz, Osmanl Medreseleri: XIX. Asır, İstanbul, 2002, s. 19-20.; Hamit Er, Osmanl Devletinde Çağdaşlaşma ve Eğitim, İstanbul, 1999, s. 23-27.; Ahmet Cihan, Reform Çağinda Osmanl İlmiyye Simifi, 2004, İstabul, s. 55-62.; Esin Kahya, Osmanlılardaki Bilimsel Çalışmalara Genel Bir Bakış, Osmanl Ansiklopedisi, Bilim, c.8., Ankara, 1999, s. 25.; Ahmet Turan Arslan, XVI. Asır Osmanli İlmi Hayatına Genel Bir Bakış, Osmanl Ansiklopedisi, Bilim, c.8., Ankara, 1999, s. 43-47.

19 A. Süheyl Ünver, İstanbul Rasathanesi, Ankara, 1969, s. 35, 47-48.

${ }^{20}$ Necdet Sakaoğlu, Bu Mülkë̈n Sultanlar: 36 Osmanl Padişahı, İstanbul, 1999, s. 189. 
III. Ahmet 1719 'da Topkapı Sarayı bünyesinde kurdurmuş olduğu kütüphanesi ile Osmanlı kütüphane kültürüne önemli katkılarda bulunmuş padişahlardandır. Bu kütüphane hem fiziksel özellikleri hem de dermesi bakımından oldukça görkemli bir kütüphanedir ve Enderun Kütüphanesi olarak da bilinir. ${ }^{21} \mathrm{I}$. Mahmut ise; 1740 'da Osmanlılardaki ilk halk kütüphanesi niteliği taşıdığı söylenen Ayasofya Kütüphanesi'ni kurmuştur. I. Abdülhamit, 1780 yılında birçok yabanc1 gezginin de bahsettiği ve kendi adıyla anılan kütüphaneyi kurmuştur. Hamidiye Kütüphanesi, İstanbul'da yabancıların da yararlanabildiği kütüphanelerden biri olarak ün kazanmıştır. ${ }^{22}$ III. Mustafa, III. Selim, Abdülmecit, Abdülaziz ve II. Abdülhamit ise; kütüphaneler kurmalarından çok dönemlerinde kütüphanelerin içinde yer aldığı eğitimöğretim kurumlarında ve vakıf yönetimleri ile ilgili yaptıkları düzenlemelerle, kütüphanelere farklı özellikler kazandırmışlardır. ${ }^{23}$ Yapılan bu yeni düzenlemelerin temelinde Osmanlı Devleti'nin XVIII. yüzyılın başından itibaren ${ }^{24}$ içinde bulunduğu askeri, siyasi, ekonomik, ahlaki, kültürel ve sosyal çöküntü yatmaktadır.

XVII. yüzyılın ikinci yarısından itibaren (1678) medrese, külliye, cami, tekke, mevlevihane ve evlerde kurulan kütüphanelere, kendine özgü mimarisi olan, yukarıda adı geçen kurumlardan bağımsız ve tam anlamıyla özgün birer kütüphane kimliği taşıyan kütüphaneler eklenmiştir. Bu tarzda kurulan kütüphanelerin ilki ve en önemlisi, Köprülü Mehmet Paşa'nın 1661 yılına yapımına başlanan ancak vefatından sonra oğlu Köprülü Fazıl Ahmet Paşa tarafından bitirilen

21 Mehmed Refik, Enderun-1 Hümayun Kütübhanesi, Tarih-i Osmani Encümeni Mecmuası, 7.cüz, 1916, s. 237.; Osman Ersoy, Türkiye'ye Matbaanın Girişi ve İlk Basılan Eserler, Ankara, 1959, s. 26.

22 Müjgan Cunbur, I. Abdülhamid Vakfiyesi ve Hamidiye Kütüphanesi, Ankara, 1965, s. 28-29.

23 Sözü edilen yenilikler ve düzenlemeler şu şekilde özetlenebilir; 1773’te Hendesehane'nin açılması ve 1784'te Batılı tarzda ilk yüksekokul olarak yeniden düzenlenerek "Mühendishane-i Bahr-i Hümayun"adını alması, 1795'te "Mühendishane-i Berr-i Hümayun”un açılması ve her iki okul içerisinde oluşturulan ve Batılı tarzda kaynakların da bulunduğu kütüphanelerin kurulması, 1857'de Maarif Nezareti'nin kurulmas1, 1869'da "Maarif-i Umumi Nizamnamesi”nin yayınlanarak kütüphanelerin Maarif Nezareti'ne devredilmesi, 1881'de Münif Paşa tarafından hazırlanan "Kütübhanelerin Suret-i İdaresi"ne ilişkin "Talimatname"nin yayınlanmas1, 1882'de İstanbul kütüphanelerinin kitap mevcutlarının belirlenmesi için "irade-i seniyye" nin yayınlanması ve Osmanlı Devleti'nde devletin kurduğu ilk halk kütüphanesi olan Beyazıt Kütüphanesi’nin (Kütübhane-i Umumi-i Osmani) açılması, 1885'te kütüphanelerin yönetiminin ve kütüphanecilerin denetiminin Maarif Nezareti'ndeki “Kütüphaneler Müfettişliği”"ne devredilmesi.

241699 Karlofça ve 1700 İstanbul Anlaşmaları. 
külliyesinden bağımsız olarak kurulan Köprülü Kütüphanesi'dir. Bu kütüphane ile birlikte Osmanlılarda kütüphane kültürü; bina, derme, hizmet, kullanıcı ve çalışanlar bakımından farklı bir boyut kazanmıştır. ${ }^{25}$ Bunun yanı sıra vurgulanması gereken bir diğer önemli nokta, XVII. yüzyılın sonları ve XVIII. yüzyılın başlarında kurulan külliyelerin içerisinde kütüphanelerin daha fazla ön plana çıkıyor olmasıdır. Bunun en önemli nedeni, devletin ekonomik ve sosyal yaşamının giderek bozulmasıdır. $\mathrm{Bu}$ dönemde külliyelerde oldukça masraflı yıllık giderleri olan hastane ve imaretlerin yerine, kütüphane ve sebiller daha fazla tercih edilmeye başlamıştır. Bu durum da şu ilginç sonucu ortaya çıkarmaktadır ki, Osmanlı Devleti'nin sözü edilen dönemlerde içine düştüğü ekonomik bunalım, eğitim-öğretimi ve kütüphaneleri olumlu yönde etkilemiş, zaten bağış ve vakıf sistemi ile yürüyen bu kurumların niceliksel de olsa artmasına yardımcı olmuştur.

Bu çöküntüyü anlayabilmek için, XVI. yüzyıldan başlayarak Avrupa ve Osmanlı'daki bilimsel ve eğitim yaşamlarına göz atmak gerekecektir. $\mathrm{Bu}$ dönemde meydana gelen değişiklikler Osmanlılarda kütüphane kültürünü ve bilimsel yaşama etkisindeki değişimi de ortaya koyacaktır.

Osmanlı Devleti, XV. yüzyılın ikinci yarısından itibaren -tarihimizde 1453 olarak bilinir- bir yükseliş dönemine girmiş, askeri ve dini sisteme dayalı devlet-yönetim yapısı ve tüm kurumlar, bu sisteme göre temellendirilmiş ve sistem işlemeye başlamıştır. Ancak, Batı kültürü, XVI. yüzyılın sonlarına doğru önce ekonomik-siyasi alanda, sonra diğer tüm değerler alanında dünya görüşü olacak kadar genişlediğinde XVI. yüzyılın ortalarından itibaren Avrupa'da başlayan bilimsel devrim, temel ve uygulamalı bilimlerin gündelik yaşamda kullanılmasına, geliştirilen teknolojinin ve yeni dünya görüşünün ekonomik ve siyasi yaşama yön vermesine ve bunun eğitim ve bilim alanlarına uygulanmasını da beraberinde getirmiştir. Bu dönemden sonra Avrupa'da bilimsel bilgiye dayalı eğitim-öğretim sistemi gelişmeye ve yaygınlaşmaya başlamış, bu da yeni bir kültürün ortaya çıkmasını sağlamıştır. Osmanlı Devleti ise; bu yeni kültürün önemini, kısmen de olsa ancak II. Viyana Kuşatması ile başlayan süreçte, 1683-1699 arasındaki savaşlarda ve daha sonra 1700, 1718, 1768, 1774, 1791 ve 1792 yıllarında aldığı büyük yenilgiler sonucunda anlayabilmiştir. Ancak siyasi yönetimin bu kavrayışından önce, XVII. yüzyılın ikinci çeyreğinde, dönemin aydınları padişahlara

${ }_{25} \mathrm{Bu}$ konu için bkz. Köprülü Kütüphanesi Vakfiyesi, Köprülü Kütüphanesi, No: 4.; Müjgan Cunbur, Vakfiyelere Göre Eski Türk Kütüphanelerinin Yönetimi. Türk Kütüphaneciler Derneği Bülteni 11 (1-2), 1962, s. 4-20.; Erünsal a.g.e., 1999, s. 61.; Özer Soysal, Türk Kütüphaneciligi - IV: Belgeler Yazıtlar / Yapı XI. - XVIII. YY. Illk Yar, Ankara 1998. s. 13., Erünsal, a.g.m., 1998, s. 240. 
Osmanlı'nın içinde bulunduğu çöküntü ve kötüye gidişin boyutlarını anlatan ve halkın bazı isteklerini ileten eserlerini sunmuşlardır. ${ }^{26}$ Batı'nın Osmanlı'ya karş1 kurmuş olduğu ittifak, bu dönemde kendini hissettirmeye başlamış, özellikle kullanılan silah ve savaş taktikleri, Osmanlıların savaş meydanlarından yenik ayrılmalarına neden olmuştur. Bunun bir sonucu olarak ekonominin bozulması halkın gelir seviyenin ve satın alma gücünün azalmasını beraberinde getirmiştir. Askeri başarısızlıklara bağlı olarak ekonominin de bozulması eğitim-öğretimin dolayısıyla da vakıf kurumlarının bozulmasına neden olmuştur.

Avrupa'da gerçekleşen Rönesans, Reform, Fransız İhtilali ve Sanayi Devrimi gibi büyük etki alanlarına sahip siyasi, bilimsel, dini ve ekonomik gelişmeler, kuşkusuz Osmanlı Devleti'ni de çeşitli yönlerde etkilemiştir. Osmanlı Devleti, bu olaylar karşısında çeşitli dönemlerde kendini savunan ve kapalı bir sistem geliştirerek karşı koymuştur. Çünkü Osmanlılar kendilerinden önce gelen tüm Türk devletleri gibi gelenekselcilik (nizam/düzen-denge) politikasını kabul etmiş ve bunun temellerinden ayrılamayarak varlığını sürdürmeye çalışmıştır.

XVI. yüzyılın sonuna kadar Osmanlı Devleti, ekonomik, siyasi, hukuki, eğitim, bilim, sanat ve kültür alanlarında en üst noktaya erişmiş durumdaydı. Bunun yanı sıra güçlü devletler ile de sınır olmuştu. Bu durumda devletin yapacağı en doğru davranış içinde bulunduğu konumu korumaya ve bunu sürdürmeye çalışmaktır ve Osmanlılar da bu yöntemi belli bir süre gerçekleştirmişlerdir. Ayrıca Avrupa'da gelişmeye başlayan bilimsel devrim ile Osmanlı Devleti'nin en görkemli dönemlerini yaşamasının aşağı yukarı aynı tarihlere rastlıyor olması, bu devrimin öneminin anlaşılmasını zorlaştırmıştır. Ancak Osmanlı Devleti'nin ele geçirdiği ticaret ve suyolları, önemli limanlar, yeraltı ve yer üstü kaynakları Avrupalı devletleri başka çözüm yolları geliştirmeye ve en kısa sürede Osmanlıları etkisiz hale getirmeye böylelikle de onlardan daha güçlü olmaya sevk etmiştir. Bunun için de bilimsel bakış açısıyla oluşturulan; farklı silahlar, teknikler, ordu düzeni, alternatif ticaret yolları, yeni dünya görüşü, yeni ittifaklar, egemenlik mücadelesi ve ekonomik sistem ile Osmanlı Devleti'nin karşısına çıkmışlardır. Sonuç, Osmanlılar için çöküşün başlangıcı olmuştur. Osmanlı Devleti, ortaya konulan yeni olguları ve uygulamaları aslında kavramakta fazla gecikmemiştir, ancak somut uygulamaları (teknoloji) alarak ya da kendi sistemine uyarlayarak kullanmıştır. Sözü edilen durumları ve gelişmeleri

${ }_{26}$ Bu konudaki en önemli yapıt, 1631'de Göriceli Koçi Bey tarafindan IV. Murat'a sunulan "Koçi Bey Risalesi”dir. Bkz. Koçi Bey Risalesi: Eski ve Yeni Harflerle, Haz: Yilmaz Kurt, Ankara, 1994. 
ortaya çıkaran düşünce sistemini almaktan ya da en azından temel niteliklerini uygulamaktan kaçınmış, devlet yönetimi ve eğitim programlarına nizam-denge yerine terakki/ilerleme-inkılap/devrim politikasını yerleştirmemiş ya da yerleştirememiştir. ${ }^{27}$ Osmanlıların bilime olan bakış açısı, pratik uygulamalar ve bilimsel buluşların uygulanmasına yönelik olmuştur. Burada bilimin üç ana unsuru olan teori (kuramsal çerçeve), araştırma ve tecrübe (uygulama-deney-gözlem) dikkate alınmıyordu. Bu yaklaşım tarzı Tanzimat öncesi dönemde Osmanlı Devleti'nin eğitim ve bilim politikasının da temelini oluşturmaktaydı. ${ }^{28}$ Ülken'nin de belirttiği gibi: "Batı kültürü önce ekonomik-siyasi alanda, sonra bütün değerler alanında dünya görüşü olacak kadar genişlediği zaman, XVI. yüzyıldan sonra onun gelişme hızına ayak uyduramayan başka kültürler için tek yol kalıyordu. Modernleşmek. Çünkü bu artık Batı ve Doğu'nun karşılaşması, kapalı eski kültür çevrelerinin alışverişi değil, dünya ölçüsünde karakteri olan yeni kültüre katılmadan başka bir şey olmayacaktı". ${ }^{29}$ Elbetteki konumuz gereği bunun eğitim-öğretim, kütüphaneler ve bilimsel yaşamla da ilişkisini belirtmek gerekecektir.

Osmanlılarda bilimsel yaşamı ve kurumları yönlendiren kuramsal çerçeve; doğaya bakarken ve doğanın bilgisini bakarken, yaratıcıyaratılan ilişkisini ön plana çıkaran ve Ortaçağ İslam Dünyası'ndan miras alınan bir yaklaşım içerisinde idi. Osmanlı eğitim sisteminin temel eğitim kadroları olan ve aynı zamanda ilmiyye sınıfını oluşturan ulema için önemli olan, doğada bulunan nesneleri ve bu nesnelerin neden olduğu olayları akli bir çaba ile anlamak değil, yaratılan olarak görülen bu unsurlarla yaratan olarak görünen tanrı arasındaki zorunlu bağlantıları kavramaktı. Bütün eğitim-öğretim sistemi bu temel çerçeve üzerine kurulmuştu ve tüm öğretim kurumları da buna göre teşkilatlandırılmışlardı. Bu kuramsal çerçeve oluşturulurken Osmanlı ulemas1 Aristo (Aristoteles), Batlamyus (Ptolemaios) ve Galen (Galenos) ile bu düşünürlerin Müslüman yorumcular tarafından hazırlanan kaynaklarından yararlanmışlardır. ${ }^{30} \mathrm{Bu}$ bağlamda, bilimler de "nakli ve akli ilimler" olarak iki temel bölümlemeye tabi tutulmuş durumdayd. Nakli ilimlerde; Kur'an, tefsir, fikıh, hadis, kelam, akaid; akli ilimlerde

${ }^{27} \mathrm{Bu}$ konuda ayrıntılı bilgi için bkz. Niyazi Berkes, Türkiye'de Căgdașlașma, İstanbul, 1973, s. 30-40.; Hilmi Ziya Ülken, Türkiye'de Çăgdas Düşünce Taribi, Ankara, 1999, 20 27, 33-49.

28 Ekmeleddin İhsanoğlu, Osmanlı Bilimine Toplu Bakış, Osmanlı Ansiklopedisi, Bilim, c.8., Ankara, 1999, s. 23.

${ }^{29}$ Ülken, a.g.e., 1999, s. 20.

${ }^{30}$ Demir, a.g.e., 2001, s. 9-10.; Kazancıgil, a.g.e., 2000, s. 15-21. 
ise; matematik, astronomi, fizik, kimya, anatomi, biyoloji, tıp yer almaktaydı. Bu ayrım aynı zamanda -özellikle eğitim-öğretim kurumları içerisinde kurulan- kütüphanelerin dermelerinde de ne tür kitapların olduğunu ortaya koymaktadır.

1839'dan 1923 y1lına kadar Osmanlı Devleti'nde medreselerin yanı sıra -özellikle Tanzimat Fermanı'ndan sonra- idadi, rüşdiye, sultani gibi ilk, orta ve yüksek eğitim kurumları (gayr-1 müslimlerin açtıkları da dahil) açılmıştır. Daha önce de ifade edildiği gibi 1924 yılında kapatılana dek medreseler, Osmanlıların temel eğitim ve bilgi üretim-aktarım kurumları olarak varlıklarını sürdürmüşlerdir. Bu kurumların bünyesinde derslerde kullanılacak ders kitapları ve yardımcı kaynak kitapların yer aldığ1 kitaplıklar ve/veya kütüphaneler kurulmuştur. Bu kütüphaneler, müderrislerin yazmış olduğu telif kitaplar, tercüme ve şerhler, talebelerin diğer bilim adamlarının eserlerinden yaptıkları istinsahlar ve vakıf sahipleri / hayırseverlerin kitap bağışları ile oluşturulmuştur. Bu şekilde oluşturulmuş olan kütüphaneler, elbette ki müderrisler ve medrese öğrencilerinin kullanımına tahsis edilmiştir, zaten bu durum vakıf olarak kurulmuş olan tüm kütüphanelerin vakfiyelerinde yer almaktadır. Kütüphanelerin bilimsel yaşama etkisi temel olarak, bu noktada göze çarpmaktadır. XIX. yüzyıla kadar vakfiyelerde ve XIX. yüzyıldan sonra hazırlanan nizamname, talimatname ve layihalarda kütüphaneleri kimlerin ve ne şekilde kullanacağı açık bir biçimde gösterilmiştir. Kütüphanelerin bilimsel yaşama etkisine örnekler vererek irdelemeden önce, Osmanlı Devleti'nin kuruluşundan yıkılışına kadar süre içerisinde kurulan kütüphanelerin ve dermelerinin sayılarına bakmakta yarar görmekteyiz.

Bu konuda ilk incelenmesi gereken, Rusçuklu Osman Beyzade Ali Fethi Bey tarafindan İstanbul'un fethinden Abdülmecit dönemine kadar olan süreçte İstanbul ve bilad-1 selase kütüphaneleri, dermelerini saptamayı amaçlayan 1851-1854 yılları arasında yapılmış "El asarü'laliyye fi hazainü'l-kütüb li Osmaniyye" adlı çalışmadır. Bu çalışmaya göre İstanbul'da o dönemin sonuna kadar (1861) kurulmuş 47 kütüphane vardır. ${ }^{31} 1890$ yılında yapılan bir çalışmada, İstanbul'daki kütüphanelerin 40'dan fazla olduğunu belirtmektedir. ${ }^{32}$ Bunun dişında Osmanlı Devleti'nde 1897 yılına kadar İstanbul ve diğer şehirlerde kurulmuş okul ve kütüphanelerin sayılarını veren 1894-1895 ve 1895-1896 yıllarında yapılan istatistikler de önemlidir. Bu istatistiklere göre; 1894-1895

\footnotetext{
${ }^{31}$ Soysal, a.g.e., c.1, 1998, s. 28, 57, 66.

32 Serkis Orpilyan, Mecelle-i Ulum - Küre-i Aržda Elyevm Mevcud Bulunan Kütübhaneler, İstanbul, 1899, s. 106-110.
} 
yıllarında İstanbul'da 47 diğer vilayetlerde 276 kütüphane ${ }^{33}, 1895-1896$ yıllarında yine; İstanbul'da 47 ve diğer vilayetlerde 276 kütüphane bulunmaktadır ${ }^{34}$. 1909'da Misır Meclis-i Nuzzar Katib-i Salisi Ahmed Zeki Bey'in hazırlamış olduğu raporda ise İstanbul'daki kütüphanelerin sayıs1 40'dan fazla olarak belirtilmektedir. ${ }^{35}$ Osmanlı Devleti'nde mevcut olan kütüphanelerin sayılarıyla ilgili birçok yerli ve yabancı kaynak bulunmakta ve çeşitli rakamlar vermektedirler. Ancak verilen bilgilerden de anlaşılacağı üzere, kütüphanelerin bölgesel olarak dağılışında önemli dengesizlikler görülmektedir. 1895-1896 yıllarında Osmanlı Devleti'nde toplam 323 kütüphane bulunmaktadır ve bunların \%14'ü İstanbul'da \%8'i Balkan vilayetlerinde, \%53'ü Anadolu vilayetlerinde, \%2'si ada vilayetlerinde ve \%23'ü de Ortadoğu ve Arap vilayetlerinde bulunmaktadır. Ancak buradaki belirleyici olan önemli bir nokta bulunmaktadır; daha önce Büyük Selçuklu, Anadolu Selçuklu, Beylikler ve İlhanlıların yönetiminde kalan ve diğerlerine göre daha eski geçmişe sahip örneğin Kastamonu, Konya, Sivas, Bursa, Musul, Halep ve İzmir vilayetlerinde diğer vilayetlere göre kütüphane ve kitap sayıları diğerlerine göre fazladır. ${ }^{36}$

Kütüphanelerin bilimsel yaşama etkisi ile ilgili olarak, öğretim görevlileri ve öğrenciler için vakfedilen bina ve kitaplarla ilgili en önemli örnek, Fatih Camii ve Külliyesi için Fatih Sultan Mehmet tarafından önce Arapça hazırlatılmış daha sonra oğlu II. Bayezit tarafindan yenilenmiş ve son olarak da Türkçeye çevrilmiş olan Fatih Vakfiyeleridir. 1493 tarihli vakfiyede “....cami-i şerifenin canib-i garbisine bir buk'a-yı latife dahi inşa buyurdular ta ki medaris-i şerifelerinde ifade-i ulum iden müderrisin ve iktibas-ı ulum-ı aliyye iden talibin-i müste'idin belki ulema-yı müstehikkinden sair muhtacin içün vakf buyurdukları kitablar içün

${ }_{33}$ Maarif-i Umumi Nezareti İdaresinde Bulunan Mekatib-i İbtidaiye, Rüscdiye, İdadiye, Aliye ile Mekatib-i Hususiye ve Ecnebiyyenin ve Dersaadetde Tabrir-i İcra Kılman ve Taşrada Mevcud Bulunan Kütübbanelerin Istatistiği, 1310-1311 Sene-i Dersiye-i Maliyesine Mabsusdur, Dersaadet, Matbaa-1 Amire, s. 5, 24-25, 57-58.

34 Maarif-i Umumi Nezareti İdaresinde Bulunan Mekatib-i İbtidaiye, Rüşdiye, İdadiye, Aliye ile Mekatib-i Hususiye ve Ecnebiyyenin ve Dersaadetde Tabrir-i İcra Kılnnan ve Taşrada Mevcud Bulunan Kütübhanelerin Istatistiği, 1311-1312 Sene-i Dersiye-i Maliyesine Mabsusdur, Darü'lHilafetü'l-Aliyye, Matbaa-1 Amire, 1901, s. 5, 23-24, 59-60.

35 Ahmed Zeki, Dersaadet Umumi Kütübhanelerinin Tanzim ve Tensikine Dair Sadr-ı Azam Hilmi Paşa Hazretlerine Takdim Olunan Takrir, Dersaadet, Matbaa-1 Ahmed İhsan, 1909. s. 5.

36 Maarif-i Umumi..., a.g.e., [y.y.], s. 24-25, 57-58.; Maarif-i Umumi..., a.g.e., 1901, s. 23-24, 59-60.; Soysal, a.g.e., c.1, 1998, s. 27-28., Cumhuriyet'in ilk yılları için ayrıca bkz. Hamit Zübeyr Koşay, Kütübhanelere Dair, Maarif Vekaleti Mecmuası, 4, 1925, s. 24-25. 
mahzen ola...", "muhtac oldukları kütübün tafsiline vakıf olub nazır yahud kaim-makam-1 nazır marifetile kütüb-i mevkufeyi ehl-i medaristen diriğ itmeyüb hıfz-1 kütüb-i mevkufelerinde sa'y-i beliğ eyleyüb" ifadeleri ile Fatih'in kurmuş olduğu Sahn-1 Seman medreselerinde görev yapan müderrisler ve eğitim gören öğrencilerin faydalanacakları kitapların korunması için bir kütüphane kurulmuş olduğu belirtilmiştir. Müderris ve öğrencilerin yanı sıra dışarıdan da gelecek olan diğer müderrislerin de gerektiği zaman faydalanabileceği belirtilmiştir. ${ }^{37}$

Fatih Sultan Mehmet döneminde sadrazamlık yapmış olan Mahmut Paşa da kurduğu külliyesinin 1474 tarihli vakfiyesinde hangi tür kitaplar vakfettiğini belirttikten sonra “...kütüb-i mezkure gubardan tanzif ve iktiza iden cülud ve mahfazaları tamir ve kıraat olunan mahalle vaz olunması bil-cümle talebe-i ulum istida itmeleriyle mucibince dolab-l mezkur marifet-i şerle küşad ve kütüb-i mezkure tadad ve tanzif olunması ..." ifadesi ile, kitapların temizlenip onarıldıktan sonra külliye içerisinde eğitim gören öğrencilere kullandırılması belirtilmiştir. ${ }^{38}$

II. Bayezit de kurdurduğu külliye içerisinde yer alan kütüphanenin kullanımıyla ilgili 1490 tarihli vakfiyesinde "...ve vakıf-1 hilafet-penah şöyle şart itdi ki mezbur medrese içinde....çün koyulan vakıf kitablar zabt ve hıfz içün mütedeyyin mümin ve emin müslüman kişi ki mezkur kitablardan ol medresede mütemekkin olan talebeye hacet oldukça şühud huzurunda..." ifadesi ile medrese içerisinde eğitim gören öğrencilere şahitler huzurunda kitapların verilebileceği belirtilmiştir. ${ }^{39}$

Osmanlı Devleti'nde ilk müstakil binaya sahip kütüphane olan Köprülü Kütüphanesi’nin 1678 tarihli vakfiyesinde “...bu mezkuratı dahi vakf ve habs idüb şöyle şart eyledim ki hizane-i kütübde zikri mürur iden huffaz-1 kütüb olanlar talebe-i uluma rehn-i kavi veyahud kafil-i meli ile virüb her altı ayda yine alub hizanede hıfz idüb ziyade meks itdirmeyeler..." ve "...kütübhanede meks idüb talebe-i ilm ve ragıbin varub hizane-i mezburede mütalaa ve istinsah idüb..." ifadeleri ile medrese öğrencilerine rehin ve kefil karşıllı̆̆ altı ay boyunca kitap ödünç

37 Özer Soysal, Türk Kütüphaneciliği-II: Kütüphane Türleri, Görevlendirme IIlkeleri, Ankara, 1998, s. 16, 71-74.; Müjgan Cunbur, Fatih Devri Kütüphaneleri ve Kütüphaneciliği, Türk Kütüphaneciler Derneği Bülteni, 6 (4), 1957, s. 4-6.; Ayr1ca bkz. Fatih Mehmed II Vakfiyeleri, İstanbul, 1938.; 901 Taribli Arapça Vakfiye'den Çeviri Türkese Vakfiye, Vakıflar Genel Müdürlüğü Arşivi, Genel 1373, Kasa 46.

38 Soysal, a.g.e., c.II., 1998, s. 18.

${ }^{39}$ Soysal, a.g.e., c.II., 1998, s. 19, 82. 
verildiği ve kütüphane içerisinde araştırma ve kitap kopyalama (çoğaltma) işlemlerinin de yapıldığı belirtmektedir. ${ }^{40}$

Ragıp Paşa Kütüphanesi'nin 1763 tarihli vakfiyesinde "kütüb-i mevkufem bi-cümletiha vaz olunub ala tarik-il-istinsah ve istiare hiçbir kıtası kütübhaneden ihrac ve bir ferde iare olunmayub mütalaa ve intifa1 ancak kütübhaneye mahsus k1lına ve gelüb mütalaa ile istifade ve istiktab ve mukabele irade iden talebe-i ulum ve muarrifini intifaindan bir dürlü men ve sarf olunmayub dilediği kitabı arz ve itadan hafiz-ı kütüb olanlar bir dürlü izhar-l acz ve iba itmeyüb teşvik ve tergib ve igraz ve terbih oluna..." ifadesi ile vakfedilen kitapların sadece kütüphane içerisinde öğrencilere ve diğer araştırmacılara çoğaltma, araştırma için ödünç verilmesi ve kütüphanecilerin de bu kimselere hizmet konusunda zorluk çıkarmamaları bilakis teşvik ve yardımcı olmaları gerektiği belirtilmektedir. ${ }^{41}$

Yusuf Ağa Kütüphanesi'nin 1795 tarihli vakfiyesi'nde “...esatize-i benam ve talebe-i kiram hasirine matlubları olan kitabları bila-tereddüd ve tevan-i tevzi ve itaya mübaseret ve bil-cümle tevarid iden erbab-ı istifadeye her vechle muamele bil-mücamele olunarak mütalaa ve istinsahlarına bila-mümanaat mukadderlerine riayet olunub ancak gerek mütalaa ve gerek istinsahı fakat derun-1 kütübhaneye münhasır ve maksur ve aslen ve katen bir kıtası harice ihrac olunmamak şartılye muhassas ve mahsur olunmağla velev ma'ar rehn ve'l-kefil haricine istinsah ve intifah içün ferd-i aferidiye bir cild kitab ida ve iare ve ledel-mütalaa ve'listinsah gerek kütüb-i zayi ve gerek evrak-1 kat olunmamasına hafız-1 kütübler ve yamakan kuşe-i çeşm-i dikkat ile nazkane iman u nezaret bade itmami'l-istifade ayni ile mahallerine vaz olunmasina..." ifadesi ile kütüphane dışına her ne suretle olursa olsun kitap çıkarılmaması, kütüphanedeki kitapların araştırma ve çoğaltma için ünlü, tanınmış kişilere ve öğrencilere verilebileceği belirtilmiştir. ${ }^{42}$

1491'de İskender Paşa tarafindan kurulan ve Mehmet Said Halet Efendi tarafından oluşturulan mevlevihane'nin 1820 tarihli vakfiyesinde kütüphane için“....hafız-1 kütübler Cuma ve Salı günleri ale's-seher der-i feyz-i eserini küşade iyleyub vürud iden taliban-ı ulum ve irfan ve aşikan safvet-nişana taltlf-i tam ve delhuşi-i ma-la-kelam ile irae ve mütalaa ve istinsah ile istincah itdirub ez her cihet..." ifadeleriyle tüm öğrencilere

${ }^{40}$ Köprülü Vakfiyesi, Köprülü Kütüphanesi, No: 4.; Soysal, a.g.e., c.II., 1998, 205, 221.

${ }^{41}$ Soysal, a.g.e., c.II., 1998, s. 207.

${ }^{42}$ Soysal, a.g.e., c.II., 1998, s. 241. 
sorgusuz araştırma, okuma ve çoğaltma için kitapların karşılıksız verileceği belirtilmiştir. ${ }^{43}$

Çeşitli kütüphane türleri, vâkıflar ve dönemlerden verilen bu örnekler de göz önüne alındığında, özellikle külliyeler içinde yer alan medreselerde, bağımsız medreselerin kütüphanelerinde, müstakil kütüphanelerde ve dini özelliği olan vakıfların kütüphanelerinde (tekke, zaviye, Mevlevihane, hankah vb.), öğrenciler ve öğretim görevlileri için herhangi bir kısttlama söz konusu değildir. Bu durum sözü edilen ve Osmanlı bilimsel yaşamını meydana getiren kimselerin, kütüphane kullanımını arttırmakta, böylelikle de bilimsel yaşama hem mekan, hem kaynak (kitap) hem de maddi katkıda bulunmaktadır. Bu açıklama yapılırken Osmanlı toplumunun; eğitim-öğretim, okuma-yazma, meraksoru sorma ve araştırma yapma durumlarının da göz önünde bulundurulması gerekmektedir.

Osmanlı eğitim-öğretim sistemi daha önce de belirtildiği gibi militer ve teokratik bir sentezden meydana gelmekteydi. Bu sentez içerisinde üç temel unsur yer almaktaydı, devleti yöneten despotik hanedan, bu hanedanın etrafında, devletin güvenliğini sağlayan ve vergi gelirlerini toplayan bir militer sınıf ve reaya denilen halk sınıfı. Devletin öncelikli görevlerinden biri de güvenliği sağlayan ve diğer bürokratik işleri yerine getirecek olan kadroların eğitmekti. Bu da tüm toplum içerisinde belirli sayı ve özellikte insanın eğitimi anlamına gelmekteydi. Osmanlı Devleti, XIX. yüzyılın başına kadar bu amaç için gerekli olan eğitim politikasını sürdürdü. Ancak asıl eğitilmesi gereken reaya için okullar, Tanzimat ve Islahat Fermanları'nın etkileriyle -özellikle de gayr-1 müslimler tarafından- açılmaya başladı. Ancak hiçbir zaman Cumhuriyet dönemindeki kadar uzun süreli olmadı ve yaygınlaştırılamadı. Bu eğitim politikası göz önüne alındığında kütüphane kullanıcılarının belirli bir zümreden kişiler olduğu da görülmektedir. Müderrisler ve talebe-i ulumların yanı sıra herhangi bir akademik kişiliğe sahip olmayan ancak bilim ve fen ile uğraşanlara (tanınmış/be-nâm) da bu firsat verilmiştir. Hatta kütüphanelerde görev alacak kütüphaneciler, (hafız-1 kütübler) müderrisler arasında da seçilmekteydi. Ortaya çıkan bu durumda, bilgiyi talep eden ve üretenler müderris ve talebeler olduğu için de kütüphanelerin hemen her türü bu kullanıcı türünü hedef olarak belirlemiştir. Halkın büyük çoğunluğu ancak temel dini konuları ve günlük pratik bilgileri anlayabilecek kadar okuma bildiği ve genelde bu konularla ilgilendiği için kütüphanelerden pek de fazla yararlanmıyorlardı. Ayrıca vâkıflar zaten az sayıda ve değerli olan

${ }^{43}$ Soysal, a.g.e., c.II., 1998, s. 317, 329. 
kitaplarını daha bilinçli kişilerin kullanmasını tercih etmekteydiler. Bu da halkın bu kurumları "kullanamamasinin" önemli bir nedenini oluşturuyordu. Fatih Külliyesi, Süleymaniye Külliyesi, II. Beyazıt Külliyesi, Selimiye Külliyesi, Mahmut Paşa Külliyesi, Köprülü Külliyesi gibi büyük vakıfların kütüphaneleri, tamamıyla bu tür kişilerin yetiştirilmesi için kurulmuş ve dolayısıyla da kütüphaneleri bu kimselere hizmet ve yardım için oluşturulmuşlardır.

Sözü edilen kurumlar bünyesinde veya müstakil binalara sahip kütüphanelerin müderrisler, talebeler ve diğer araştırmacılara hizmet verme tercihlerinden biri de dil konusudur. Bilindiği üzere Osmanlıların temel eğitim kurumları olan medreselerde eğitim-öğretim dili Arapça idi. $\mathrm{Bu}$ nedenle akli ve nakli bilimlerde (müfredat doğrultusunda) hazırlanan ders kitapları, yazılan şerhler ve çoğaltılan ders kitapları da Arapça olarak yazılmaktaydı. Bunun yanı sıra, Büyük Selçuklu ve Anadolu Selçuklu Devletleri'nin de mirasçısı olan Osmanlı Devleti, bu devletlerde sıklıkla kullanılan -hatta resmi dili olan- Farsça'yı da genelde saray çevresinde ve edebiyatında kullanmaktaydı. Osmanlı Devleti'nin yükselme dönemine girmesine kadar geçen süre içerisinde, kurulan medreselerde görev yapacak müderrisler o dönemde bilim, kültür ve sanat yönünden ileri olan Şam, Bağdad, Halep, İskenderiye, Kudüs, Semerkand, Horasan gibi şehirlerdeki medreselerde eğitim görmüş ve sözü edilen dillerde yazılmış kitaplarını da beraberlerinde getirmişlerdir. $\mathrm{Bu}$ da medreselerde XV. yüzyılın ortalarına kadar, eğitim-öğretim dilini ve kaynaklarını etkilemiş̧ir.

1728'de kurulan matbaa da kütüphanelerin dermelerinin çeşitlenmesi ve daha fazla kullanılmasina neden olan temel etmenlerden biridir. Tanzimat dönemine kadar matbu eserlerin sayısında da önemli artışlar olmuştur. Açılan okullarda ve kütüphanelerde çeşitli matbaalarda basılan eserler, daha yoğun olarak kullanılmaya başlamış, en azından bir kaynaktan birden fazla öğretim görevlisi ve/veya öğrencinin yararlanması kolaylaşmıştır. 1895-1896 istatistiklerine bakıldığında özellikle İstanbul'daki kütüphanelerde bulunan matbu eserlerin sayısının önemli ölçüde artmış olduğu göze çarpmaktadır. ${ }^{44}$ Ders kitapları, edebiyat ve diğer konularda yazılmış telif kitaplar, çeviriler, süreli yayınlar, dil kitapları; matbaa ile daha kısa sürede ve ucuza basılabiliyordu.

Osmanlı Devleti'nin de çeşitli dönemlerinde basın-yayın, eğitim, kültür ve kütüphaneleri etkileyen bir diğer önemli nokta, Osmanlıların

44 Maarif-i Umumi...., a.g.e., Dersaadet, Matbaa-1 Amire, s. 5, 24-25, 57-58.; Maarif-i Umumi..., a.g.e., Darü'l-Hilafetü'l-Aliyye, Matbaa-1 Amire, 1901, s. 5, 23-24, 5960. 
XVIII. yüzyılın ortalarından itibaren çeşitli alanlarda ilişkileri devam ettirdiği Batı dünyasına hızlı bir açılım içerisinde olmasıdır. Bu açılım, Osmanlı Devleti'nin siyasi politikalarını da önemli ölçüde şekillendiren bir değişim ve ilerleme süreci olmuştur. Ancak, Avrupalı devletlerin Osmanlı'nın egemen olduğu bölgeler üzerindeki mücadeleleri, Osmanlı'nın çağın ekonomik koşullarına ayak uyduramaması gibi sorunlar nedeniyle dönem dönem ilerleme ve yenilenme karşıtllğ 1 (Batı karşıtllı̆̆1) ön plana çıkmıştır. Bu dönemlerde uygulanan yasaklar ve sansür, aslında bir bakıma karşı olunan ve Osmanlı'nın geleneksel eğitim-öğretim sistemiyle çelişen pozitif bilimlerin yaygınlaşmasına istemeden de olsa ön ayak olmuştur. Sözü edilen dönemlerde ${ }^{45}$ tarih, dil ve edebiyat gibi sosyal bilim alanlarında sürdürülen sansür ve yasaklar, fen bilimlerinin daha fazla gündeme gelmesine, bu alanlardaki yayınların artmasına, bilimsel çevrelerin yanı sıra halk arasında da yaygınlaşmasına neden olmuştur. Bu durum, kütüphanelerdeki dermenin de çeşitlenmesini ve çoğalmasını sağlamıştır.

Günümüzde yapılan sınıflamaya yakın bir düzenlemeyi Osmanlı vakıf kütüphanelerinin kullanıcılarına göre yapmak da mümkündür. Saraylarda, evlerde, konaklarda vb. mekanlarda kurulan kütüphaneler, özel kütüphanelere; medrese ve XVIII. yüzyıldan sonra darülfünun, hendesehane, mühendishane ve mesleki-bilimsel cemiyetlerde kurulan kütüphaneler okul ve araştırma kütüphanelerine; cami, türbe, vb. içerisinde kurulan kütüphaneler halk kütüphanelerine örnek olarak verilebilirler. Ayrıca müstakil olarak kurulmuş kütüphaneler de genellikle araştırma kütüphanesi olarak hizmet vermişlerdir. XIX. yüzyıl başlarında Avrupa ile başlatılan yakın siyasi ve eğitim-öğretim ilişkileri, bir bakıma bu dönemde ortaya çıkan eğitim programlarıyla doğru orantılı olarak kütüphane dermelerine de yansımıştır. Daha önce de belirtildiği gibi

Osmanlı Devleti'nin askeri alanda uğradığı yenilgiler, yenilik çalışmalarının askeri eğitim alanında yoğunlaşmasına neden olmuştur. 1773 yılında Hendesehane ile başlayan Batılı modeldeki eğitim kurumları, 1784'te Mühendishane-i Bahr-i Hümayun, 1792'de Humbarahane, 1795'te Mühendishane-i Berr-i Hümayun, 1827'de Harb Okulu, 1831'de Mizıka-i Hümayun ve 1834'te Tibhane-i Amire'nin açılması kütüphanelerin de hem mekan, hem derme hem de bilimsel yaşama olan etkisinde gelişmeleri ile devam etmiştir. Bu okulların hemen tümünde derslere yardımcı olacak edebiyat, tarih, coğrafya ve nakli ilimlere ait Türkçe, Arapça ve Farsça eserlerin yanı sıra tıp, eczacılık, biyoloji, kimya, astronomi, fizik, geometri, matematik, trigonometri,

45 II. Mahmut (1808-1839) ve II. Abdülhamit (1876-1908). 
veterinerlik, jeoloji, botanik, zooloji vb. uygulamalı bilimlerden de Fransızca, İngilizce ve Almanca eserler ${ }^{46}$ kütüphanelerde daha çok sayılarda ve çeşitlilikte yer almaya başlamıştır.

Osmanlı bilimsel yaşamına etki eden kurumlara, XIX. yüzyılın ortalarında kurulmaya başlayan bilimsel ve mesleki dernekler de katılmıştır. İlk örnekleri XVII. yüzyıl görülen bu dernekler, bilimin ve bilimsel çabaların sevdirilmesi ile XVIII. yüzyılda Batı'da kurulmaya başlanmış ve XIX. yüzyılın ikinci yarısında ise Osmanlı Devleti'ni de etkilemeye başlamıştır. $\mathrm{Bu}$ dernekler, akademisyenlerin, seçkinlerin merkezleri olmuş, bilim üretimi, yayılması, meslektaşlar arası iletişimin sağlanması, yayın yapma, bilimsel ve mesleki araştırmaların desteklenmesine ön ayak olmuşlar, okullarda, derneklerde, öğrencilere ve halka konferanslar verip çeşitli bilimsel yayınlar yapmışlardır. ${ }^{47}$ Napoli'de 1560'da Napoli Akademisi, 1651'de Floransa'da Academia del Cimento, Fransa'da 1635'te Fransiz Bilimler Akademisi (Academie Français - Academie des Sciences), İngiltere'de 1645'te İngiliz Bilimler Akademisi (Royal Society) ve St. Petersburg'da 1727'de kurulan St. Petersburg Akademisi, bu derneklerin en önemlileridir. Bu derneklerin kuruluşunda İhsanoğlu'nun da belirttiği gibi iki girişim söz konusudur. $\mathrm{Bu}$ dernekler ya devlet tarafindan, devletin bilime verdiği önem ve destek göstergesi olarak ya da toplum içerisinde eğitim görmüş kişi veya zümre tarafından kurulmuşlardır. ${ }^{48}$ Osmanlı Devleti'nde kurulan derneklerin büyük çoğunluğu ikinci tür yapılanmaya sahip derneklerdir. $\mathrm{Bu}$ derneklerden konumuz bağlamında üzerinde durulacak olanlar ise, Encümen-i Daniş, İstanbul Rum Cemiyet-i Edebiyyesi (Ellinikos Fillopikos Sillogos), Tercüme Cemiyeti ve Cemiyet-i İlmiyye-i Osmaniyye'dir.

46 Emre Dölen, Tanzimat'tan Cumhuriyet'e Bilim, Tanzimat'tan Cumburiyet'e Türkiye Ansiklopedisi, c.1., İstanbul, 1985, s. 134-196.; İlhan Tekeli ve Sevim İlkin, Osmanl Imparatorluğu'nda Eğitim ve Bilgi Üretim Sisteminin Oluşumu ve Gelişimi, Ankara, 1999, s. 30-31.; Ekmeleddin İhsanoğlu, Modern Bilimlerin Türkiye’ye Girişi, 75. Yalında Türkiye'de Sosyoloji içinde (85-124). Yay. Haz: İsmail Coşkun. İstanbul, 1991, s. 106120.

47 İsmail Doğan, Osmanl Bilimsel Topluluklarmn Türkiye'deki Bilim Eğitimine Etkileri, Ankara Üniversitesi Eğitim Bilimleri Fakültesi Dergisi, 26 (1), 1993, s. 131-132.; Ekmeleddin İhsanoğlu, Modernleşme Süreci İçinde Osmanlı Devletinde ilmi ve Mesleki Cemiyetleşme Hareketlerine Genel Bir Bakış, Osmanl İmi ve Mesleki Cemiyetleri. I. Milli Türk Bilim Taribi Sempozyumu içinde (1-42). Yay. Haz: Ekmeleddin İhsanoğlu, İstanbul, 1987, s. 1.

48 Richard S. Westfall, Modern Bilimin Olusumu, Ankara, 2004, s. 132-133.; Cemal Y1ldırım, Bilim Taribi, 8. bs., İstanbul, 2003, s. 113.; İhsanoğlu, a.g.e., 1987, s. 2. 
1851'de kurulan Encümen-i Daniş, Osmanlı Devleti'nde "cemiyet" adı ile oluşturulan ilk dernek olarak karşımıza çıkmaktadır. Bu dernek devlet tarafindan "...ammeye ehem-i elzem olan kitablarin bir an akdem vücuda getirilmesi için eshab-l hüner ve maariften mürekkeb bir cemiyet teşkiline lüzum görülerek..."49 temel görüşüyle, derneğin amaçları, eğitim ve kültür alanında gerekli çalışmaları yapmak, Batı'daki bilimsel çalışmaları ve yenilikleri izlemek, Türk dilinde bilim ve fenlere dair gerekli kitapları hazırlamak veya çevirmek, bilimsel bilginin ülkede yayılması, vatandaşların bundan istifâdesiyle umûmî seviyeyi yükseltmek olarak tespit edilmişti. Bu bağlamda ele alındığında Encümen-i Daniş’in doğrudan doğruya kütüphanelerin gelişimiyle ilgisi yoktur. Ancak dolaylı olarak, okulların kütüphanelerinde yer alabilecek Batı bilimine ait sosyal ve uygulamalı bilimler alanlarındaki kitapların Türkçe'ye kazandırılmasında yararlı olduğu da bir gerçektir.

İstanbul Rum Cemiyet-i Edebiyyesi, faaliyetleri ve çalışmaları bakımından Osmanlı Devleti içerisinde kurulan en önemli gayr-1 müslim derneklerden biridir. 1861 yılında İstanbul'da kurulmuş ve çalışmalarına 1912 yılına kadar devam etmiştir. Bu derneğin yönetici ve üyeleri, dil bilmelerinin de avantajıyla Avrupa'daki bazı ünlü bilim akademilerinin de fahri üyeliğini yapmakta, bilimsel çalışmaları desteklemekte ve ayrıca çeşitli dillerden farklı konulardaki eserleri çevirmekteydiler. Bu derneğin bünyesinde bu şekilde bir araya getirilmiş; tarih, arkeoloji, coğrafya, edebiyat, dil bilim vb. alanlarda eserleri içeren önemli bir kütüphanesi de mevcuttur. Her ne kadar bu dernek, kendi azınlığı yararına çalışmalar yapmış olsa da 1933'te Atatürk'ün direktifiyle derneğin kütüphanesinin büyük kısmı (tarih ve arkeoloji) Türk Tarih Kurumu Kütüphanesi'ne devredilmiştir.

Tercüme Cemiyeti, 1866'da Maarif-i Umumiye Nezareti'ne bağlı olarak kurulmuştur. ${ }^{50} \mathrm{Bu}$ derneğe benzer bir oluşum, (Tercüme Heyeti) 1720-1730 yılları arasında Sadrazam Nevşehirli Damat İbrahim Paşa'nın da çabalarıyla, Arapça ve Farsça eserlerin Türkçeye çevrilmesi ve “...erkan-l devletin veya vükela-ı saltanatın mütalaasina sunmak..." ", amaciyla kurulmuş ve Patrona Halil isyanına kadar çalışmalarına devam etmiştir. Tercüme Cemiyeti, Encümen-i Daniş’in aksine okullar için değil halk için kitapların yazılmasını ve klasik kitapların çevrilmesini amaçlamaktaydı. Bu iki derneğin yaptığı

49 İhsanoğlu, a.g.e., 1987, s. 6.

50 Mahmud Cevad ibnü'ş-şeyh Nafi, Maarif-i Umumiye Nezareti Tarihçe-i Teşskilat ve Ícraat, [yayl. y.], 1922, s. 90-91.

51 İhsanoğlu, a.g.e., 1987, s. 6. 
çalışmalar doğrudan kütüphaneleri zenginleştirmek ile ilgili değilse de dolaylı olarak ülke içerisindeki yayın çeşitliliğine ön ayak olmuşlardır. Bunun yanı sıra Tercüme Cemiyeti halk eğitimini de ön plana çıkararak, Osmanlı Devleti'nde bilginin toplumsallaşması için yapılan çalışmalara da önemli bir örnek olarak görülmektedir. $\mathrm{Bu}$ cemiyete benzer niteliklerde bir çalışma grubu (Telif ve Tercüme Heyeti) Cumhuriyet'in ilk yıllarından itibaren özellikle de Hasan Ali Yücel'in katkılarıyla birçok yabancı dünya klasiğini Türkçeye çevirmiştir.

Cemiyet-i İlmiyye-i Osmaniyye 1862'de Münif Paşa'nın öncülüğünde İstanbul'da kurulmuştur. Bu dernek, Osmanlı bilimsel yaşamı içerisinde birçok ilki de ortaya koymuştur. Dernek Osmanlı Devleti'nde kurulan gerçek anlamda ilk bilimsel ve mesleki dernektir. Bunun yanı sıra derneğin yayın organı olan Mecmua-i Fünûn, ilk bilimsel dergi niteliği taşımaktadır. Kütüphanecilik açısından ele alındığında ise; 1862'de derneğin bünyesinde oluşturulan kütüphane ilk dernek kütüphanesi olarak tarihe geçmiştir. Cemiyet-i İlmiyye-i Osmaniyye'nin kuruluş amac1; Mecmua-i Fünûn ve Tercüman-1 Ahval'de yayımlanan nizamnamesine göre; "Cemiyyet-i Ilmiyye-i Osmâniyye kitâb telîf ve tercümesi ve umûmî ders itâsı ve'l-hâsıl her türlü vesâit-i mümkûne ile memâlik-i mahrûsa-i şâhânede inşâr-ı ulûm ve fünûna say ve ikdâm idecekdir. Cemiyyet ulûm ve maârife ve ticâret ve sinâyı dâîr Mecmûa-ı Fünûn unvânıyla beher mâh ibtidâsında bir gazete çıkaracak ve işb̂ิ mecmûa lâ-âkall otuz iki sahifeden ibâret olarak azânin cümlesine meccânen birer nüshası itâ olunacakdır. Cemiyyet mesâill-i diniyye ve zamân-ı hâl-i politikası mübâhisinden ihtirâz idüb kendûsüne takdîm olunan lâyihâlariñ dahi mevâd-ı mezkûreden arî olmasına dikkat ve itinâ idecekdir. ",52 şeklinde belirlenmiştir.

Eğitim - öğretimde sadece okulların ve medreselerin değil bu kurumların dışında kitap ve gazetelerin okunmasının da büyük yararlar sağlayacağı, bunun da derneğin asıl görevlerinden olduğunu belirterek dernek bünyesinde bir kütüphane oluşturulması kararlaştırılmıştır. Kütüphane, Cemiyet-i İlmiyye-i Osmaniyye'nin merkezinde her kesimden vatandaşın yararlanabileceği, çeşitli konu ve dillerde kitap ve süreli yayını (yaklaşı 1000 cilt) bulundurmaktaydı ve bunların büyük çoğunluğu fen ve uygulamalı bilimlerden oluşmaktaydı. ${ }^{53}$ Bunun yanı

52 Mecmua-i Fünun, 1 (1), 1862, s. 2. (1., 2. ve 3. maddeler).; Ekmeleddin İhsanoğlu, Cemiyet-i İlmiyye ve Mecmua-i Fünun, Osmanl İmi ve Mesleki Cemiyetleri. I. Milli Türk Bilim Taribi Semposyumu içinde (221-254). Yay. Haz: Ekmeleddin İhsanoğlu, İstanbul, 1987, s. 227.

53 Mecmua-i Fünun, 1 (1), 1862, s. 14-15. 
sıra dernek bünyesinde bir kıraathane de kurulmuş ve burası için çeşitli dillerde günlük ve haftalık gazeteler alınmıştır. ${ }^{54}$

Kütüphanelerin bu şekildeki gelişiminden sonra, son olarak kütüphanelerin Osmanlı Devleti'nin son dönemindeki siyasi kimlik yönünden gelişimini irdelemek gerekmektedir. Osmanlı Devleti, XIX. yüzyıl sonu ile XX. yüzyıl başlarında dağılma döneminin içinde yer almaktaydı ve topraklarının büyük bölümünü 1877-1878, 1911, 19111912, 1912-1913 savaşlarında kaybetti. 1908'de II. Meşrutiyet'in ilanıyla başlayan yeni siyasi süreç, Osmanlı içerisinde farklı siyasi görüşler ortaya çıkmıştır. 1876-1908 yılları arasında etkili olan İslamcılık, Arnavutluk ve Makedonya'nın kaybı, Ortadoğu'daki isyanlar ve II. Meşrutiyet'in ilanı ile son bulmuş ona alternatif olarak gelişen Osmanlıcılık, Trablusgarb ve Balkan Savaşları ile sona ermiştir. Bunların ardından gelişen Türkçülük akımı ise 1914-1918 yılları arası etkisini göstermiş ve savaştan yenik çıkılmasıyla son bulmuştur. Kütüphanecilik tarihimizde önemli olan akım ise son dönem siyasi hayatına yön veren ve İttihat ve Terakki Cemiyeti tarafından şekillendirilen Türkçülük akımıdır. Dönemin siyasi partileri özellikle- İttihat ve Terakki, parti programlarında ve iç tüzüklerinde milli kütüphane kurulması için girişimlerde bulunacaklarını belirtmişlerdir. 1908-1918 yılları arası Osmanlı siyasi hayatında önemli yere sahip olan İttihat ve Terakki Cemiyeti, 1911 yılında düzenlediği IV. Kongresi’nde kütüphane kurma, yönetme, geliştirme ve yaygınlaştırma çalışmalarını toplumsal ve kültürel alanlarda siyasi programına alarak, hükümete önermiş ve bu işlemlerin devlet eliyle yapılmasını resmileştirmiştir. ${ }^{55}$ 1913 yılında kabul edilen siyasi programının Kısm-1 Maarif başlıklı bölümünün 44. maddesinde milli bir kütüphane kurulması gerektiği "Milli hayat-ı irfanımızı selim bir inkişaf vermek üzere bir Encümen-i Daniş teşkili ve mekatibde tedris edilmek üzere elsine-i muhtelife üzerine kitablar telif idecek bir heyet tayini ve mühim ve nafi asar-ı ecnebiyyenin lisanımıza nakli için bir tercüme encümeninin teşkili, bilumum kütüphanelerin imar ve idame-i intizamlarl ve pay-i tahtta mükemmel bir

54 Mecmua-i Fünun, 1 (1), 1862, s. 2-10.; Mecmua-i Fünun, 2 (22), 1864, s. 423.; Necdet Hayta, Cemiyet-i İlimiye-i Osmaniye ve Mecmua-i Fünun, Türk Kültürü, 36 (428), 1998, s. 731-733.; Müjgan Cunbur, Münif Paşa ve Kütüphanelerin Yönetimiyle İlgili İlk Resmi Talimatname, Türk Kütüphaneciler Derneği Bülteni, 13 (1-2), 1964, s. 30-35., Müjgan Cunbur, Tanzimat'nn Kütüphaneciliğimize Etkileri, Belleten, 28 (112), 1964, s. $692-697$.

55 Özer Soysal, XIX. ve XX. Yüzyıllar Osmanlı Siyasal Yaşamının Kütüphane Kurumunu Etkileyen İki Olgusu, VIII. Türk Tarih Kongresi Bildirileri c.2. içinde (1113-1125), Ankara, 1981, s. 1117. 
kütüphane-i milli tesisi teklif olunacaktır." şeklinde belirtilmiştir. ${ }^{56}$ Bunun yanı sira 1917 y1lında VIII. kongresinde siyasal programda istenilen değişiklik konuları arasında da milli kütüphane kurulması tekrar vurgulanmıştır. ${ }^{57} \mathrm{O}$ dönemde kurulan diğer partiler de bu konuda siyasal programlarında ve nizamnamelerinde yer vermişler, dönemin çeşitli siyasi görüşlerdeki gazete ve dergileri bu konu ile ilgili yayınlar yapmışlardır.

\section{Sonuç}

Osmanlılarda kütüphane kültürü, tarihsel gelişim süreci içinde çeşitli fiziksel, hukuksal, siyasi ve ekonomik değişimler göstermiştir. İlk dönemlerinde (1331-1453) saray ve medreselerde yoğun olarak kurulmaya başlayan kütüphaneler, 1453 'ten sonra önemli bir sıçrama yaparak eğitim-öğretim kurumlarının vazgeçilmez parçaları olmuşlardır. Bu noktada bilimsel yaşama da katkıları önemli ölçüde artmıştır. Fiziksel özellikleri, dermeleri, personeli ve hizmetleri ile aynı zamanda vakıf kurumları olan kütüphaneler, Osmanlılarda kültürün de önemli bir parçasını meydana getirmişlerdir. $\mathrm{Bu}$ özelliklerini hem çeşitli dönemlerde, farklı alanlarda bilim adamları, sanatçılar, devlet büyükleri vb. yazmış veya çevirmiş olduğu eserleri korumak hem de bilimsel yaşamda yeni bilgi üretmek için aktarmak üzere kullanmışlardır.

Kütüphaneler Osmanlı Devleti'nin farklı dönemlerinde içinde bulunulan ekonomik, kültürel ve siyasi olaylardan ve politikalardan etkilenmişler, kendilerini bu unsurlara göre yeniden kurgulamışlardır. Osmanlılarda, kütüphaneler hem kültürün bir parçası hem de oluşan kültürü aktaran ve gelişmesini sağlayan kurumlar olarak varlıklarını sürdürmüşler, kuruldukları tarihten itibaren de bilimsel yaşamın en büyük destekçileri olmuşlardır.

\section{Kaynakça}

AHMED ZEKİ. (1909). Dersaadet Umumi Kütübhanelerinin Tanzim ve Tensikine Dair Sadr-1 Azam Hilmi Paşa Hazretlerine Takdim Olunan Takrir. Dersaadet: Matbaa-1 Ahmed İhsan.

\footnotetext{
${ }^{56}$ Soysal, a.g.m., 1981, s. 1117.; Tar1k Zafer Tunaya, Türkiye'de Siyasi Partiler Cilt I: İkinci Meşrutiyet Dönemi 1908-1918. Gnş 2. bs., İstanbul, 1984, s. 110.

57 Tunaya, a.g.e., 1984, s. 122.
} 
AYVERDİ, Ekrem Hakk1. (1966). Osmanlı Mimarisinin İlk Devri - I. İstanbul: İstanbul Fetih Derneği İstanbul Enstitüsü.

BERKES, Niyazi. (1973). Türkiye'de Çağdaşlaşma. İstanbul: Bilgi Yayınevi.

BLOOM, Jonathan M. (2003). Kâğıda İşlenen Uygarlık: Kâğıdın Tarihi ve İslam Dünyasına Etkisi. Çev: Zülal Kılıç. İstanbul: Kitap Yayınevi.

“Cemiyet-i İlmiyye-i Osmaniyye Nizamnamesidir". (1862). Mecmua-i Fünun 1 (1): 2-10.

“Cemiyet Kütübhanesi Nizamnamesidir”. (1862). Mecmua-i Fünun, 1 (1): 14-15.

“Cemiyet Merkezinde Kıraathane Küşadı”. (1864). Mecmua-i Fünun, 2 (22): 423-427.

“Corvin Könyvtár". (1997). Magyar Nagy Lexikon. c.5. (620-621). Edi: László Élesztös, Budapest: Magyar Nagylexikon Kiadó.

CUNBUR, Müjgan. (1969). "Fatih'in Kurduğu Kütüphaneler”. Önasya 4 (45): 6-7.

CUNBUR, Müjgan. (1965). I. Abdülhamid Vakfiyesi ve Hamidiye Kütüphanesi. Ankara: Ankara Üniversitesi.

CUNBUR, Müjgan. (1962). "Vakfiyelere Göre Eski Türk Kütüphanelerinin Yönetimi”. Türk Kütüphaneciler Derneği Bülteni 11 (1-2): 3-21.

ÇORUH, Hakkı Şinasi. (1972). "Fatih'in Kütüphane Memuru, Büyük Türk Ansiklopedisti Molla Lütfi ( - ?/1494)". Türk Kültürü 10 (115): 435-442.

DEMIR, Remzi. (2001). Osmanlılar'da Bilimsel Düşüncenin Yapısı. Ankara: Epos Yayınları.

DOĞAN, İsmail. (1993). "Osmanlı Bilimsel Topluluklarının Türkiye'deki Bilim Eğitimine Etkileri”. Ankara Üniversitesi Eğitim Bilimleri Fakültesi Dergisi, 26 (1): 131-149.

DÖLEN, Emre. (1985). "Tanzimat'tan Cumhuriyet'e Bilim", Tanzimat'tan Cumhuriyet'e Türkiye Ansiklopedisi, c.1. İstanbul: İletişim Yayınları. 
ECHE, Youssef (1963). Les Bibliothèques Arabes Publiques et SemiPubliques en Mèsopotamie, Syrie et en Egypte au Moyen Age. Damascus: Institut Français de Damas.

EMSEN, Şemim. (1960). "Osmanlı İmparatorluğu Devrinde Türkiye Kütüphaneleri Tarihi”, Türk Kütüphaneciler Derneği Bülteni 9 (12): 14-35.

ERSOY, Osman. (1959). Türkiye'ye Matbaanın Girişi ve İlk Basılan Eserler. Ankara: Güven Basımevi.

ERÜNSAL, İsmail.E. (1999). “Osmanlı Kütüphanelerinin Tarihi Gelişimi”, Osmanlı Devleti'nde Bilim, Kültür ve Kütüphaneler içinde (235-246). Yay. Hazl. Özlem Bayram [ve diğerleri]. Ankara: Türk Kütüphaneciler Derneği.

ERÜNSAL. İsmail E. (1991). Türk Kütüphaneleri Tarihi - II: Kuruluşundan Tanzimat'a Kadar Osmanlı Vakıf Kütüphaneleri. Ankara: Atatürk Kültür Merkezi.

GÖKDOĞAN, Melek DOSAY ve Yavuz UNAT. (2004). "Fatih Dönemi (1451-1481) Bilim Anlayışı ve Bilim Adamları". İstanbul'un Fethinin 550. Yılı Anı Kitabı içinde (35-46). Edi: Esin Kahya ve Ayten Aydın, Ankara: Ankara Üniversitesi.

GÖKMAN, Muzaffer. (1939). İstanbul Kütüphaneleri ve Bugünkü Durumları. İstanbul: Hüsnütabiat.

İHSANOĞLU, Ekmeleddin. (1999). "Osmanlı Bilimine Toplu Bakış", Osmanlı Ansiklopedisi, Bilim, c.8. (17-24). Ankara: Yeni Türkiye Yayınları.

İHSANOĞLU, Ekmeleddin (1991). "Modern Bilimlerin Türkiye'ye Girişi”, 75. Y1lında Türkiye'de Sosyoloji içinde (85-124). Yay. Hazl: İsmail Coşkun. İstanbul: Bağlam Yayıncılık.

İHSANOĞLU, Ekmeleddin (1987). "Modernleşme Süreci İçinde Osmanlı Devletinde ilmi ve Mesleki Cemiyetleşme Hareketlerine Genel Bir Bakış”. Osmanlı İlmi ve Mesleki Cemiyetleri. I. Milli Türk Bilim Tarihi Sempozyumu içinde (1-42). Yay. Hazl: Ekmeleddin İhsanoğlu, İstanbul: İstanbul Üniversitesi Edebiyat Fakültesi.

İHSANOĞLU, Ekmeleddin. (1987). "Cemiyet-i İlmiyye ve Mecmua-i Fünun”. Osmanlı İlmi ve Mesleki Cemiyetleri. I. Milli Türk Bilim Tarihi Sempozyumu içinde (221-254). Yay. Hazl: Ekmeleddin İhsanoğlu, İstanbul: İstanbul Üniversitesi Edebiyat Fakültesi. 
KAZANCIGIL, Aykut. (2000). Osmanlılarda Bilim ve Teknoloji. İstanbul: Ufuk Kitapları.

"Korvin". (1915). Révai Nagy Lexikon. c.12. (62-64). Az Ismeretek Enciklópédiá, Budapest: Révai Testvérek Irodalmi Intézet Résztevény Társoság,

“Köprülü Kütübhanesi Vakfiyesi”. Köprülü Kütüphanesi, No: 4.

"Maarif-i Umumi Nezareti İdaresinde Bulunan Mekatib-i İbtidaiye, Rüşdiye, İdadiye, Aliye ile Mekatib-i Hususiye ve Ecnebiyyenin ve Dersaadetde Tahrir-i İcra Kılınan ve Taşrada Mevcud Bulunan Kütübhanelerin İstatistiği: 1310-1311 Sene-i Dersiye-i Maliyesine Mahsusdur. Dersaadet: Matbaa-1 Amire.

"Maarif-i Umumi Nezareti İdaresinde Bulunan Mekatib-i İbtidaiye, Rüşdiye, İdadiye, Aliye ile Mekatib-i Hususiye ve Ecnebiyyenin ve Dersaadetde Tahrir-i İcra Kılınan ve Taşrada Mevcud Bulunan Kütübhanelerin İstatistiği: 1311-1312 Sene-i Dersiye-i Maliyesine Mahsusdur. (1901). Darü'l-Hilafetü'l-Aliyye: Matbaa-1 Amire.

MAHMUD CEVDET İNBÜ'Ş-ŞEYH NAFİ. (1922). Maarif-i Umümiye Nezareti Tarihçe-i Teşkilat ve İcraatı. İstanbul: Matbaa-i Amire.

MAKDISI, George. (2004). Ortaçağ'da Yüksek Öğretim: İslam Dünyası ve Hıristiyan Batı. Çev: Ali Hakan Çavuşoğlu ve Hasan Tuncay Başoğlu. İstanbul: Gelenek Yayıncılık.

MEHMED REFIK. (1916). "Enderun-1 Hümayun Kütübhanesi”. Tarih-i Osmani Encümeni Mecmuas1 (7): 236-241.

ORPILYAN, Serkis. (1899). Mecelle-i Ulum. İstanbul: Karabet Matbaas1.

PAKALIN, Mehmet Zeki. (1983). Osmanlı Tarih Deyimleri ve Terimleri Sözlüğü. c.2. Ankara: Milli Eğitim Bakanlığı.

RUKANCI, Fatih and Hakan ANAMERİÇ. (2006). "Libraries as Scientific, Educational and Cultural Institutions in the Otoman Empire (XIVth-XVIIth Centuries), Libri, 56 (4): 252-263.

SAKAOĞLU, Necdet. (1999). Bu Mülkün Sultanları: 36 Osmanlı Padişahı. İstanbul: Oğlak Yayıncılık ve Reklamcılık Ltd. Şti.

SEFERCIOĞLU, Necmeddin. (1999).“Osmanlı Döneminde Kütüphane Katalogları”, Osmanlı Devleti'nde Bilim, Kültür ve Kütüphaneler içinde (143-152). Yay. Hazl. Özlem Bayram [ve diğerleri]. Ankara: Türk Kütüphaneciler Derneği. 
SOYSAL, Özer. (1998). Türk Kütüphaneciliği - I: Geleneksel Yapıdan Yeniden Yapılanışa. Ankara: Kültür Bakanlığı.

SOYSAL, Özer. (1998). Türk Kütüphaneciliği - II: Belgeler Kütüphane Türleri, Görevlendirme İlkeleri. Ankara: Kültür Bakanlığı.

SOYSAL, Özer. (1998). Türk Kütüphaneciliği - IV: Belgeler Yazıtlar / Yapı XI. - XVIII. YY. İlk Yarı. Ankara: Kültür Bakanlığı.

SOYSAL, Özer. (1981). "XIX. ve XX. Yüzy1llar Osmanlı Siyasal Yaşamının Kütüphane Kurumunu Etkileyen İki Olgusu", VIII. Türk Tarih Kongresi Bildirileri c.2. içinde (1113-1125), Ankara: Türk Tarih Kurumu.

ŞEHSUVAROĞLU, Bedi N. (1978). "Tarihte ve Bizde Kütüphane". Türk Kütüphaneciler Derneği Bülteni 27 (1): 1-9.

TEKELİ, İlhan ve Sevim İlkin (1999). Osmanlı İmparatorluğu'nda Eğitim ve Bilgi Üretim Sisteminin Oluşlumu ve Gelişimi. Ankara: Türk Tarih Kurumu.

TUNAYA, Tarık Zafer. (1984). Türkiye'de Siyasi Partiler Cilt I: İkinci Meşrutiyet Dönemi 1908-1918. Gnş 2. bs., İstanbul: Hürriyet Vakfı Yayınları.

ÜLKEN, Hilmi Ziya. (1999). Türkiye'de Çağdaş Düşünce Tarihi. Ankara: Ülken Yayınları.

ÜNVER, A. Süheyl. (1969). İstanbul Rasathanesi. Ankara: Türk Tarih Kurumu.

ÜNVER, A. Süheyl. (1952). "İkinci Selim'e Kadar Osmanlı Hükümdarlarının Hususî Kütüphaneleri Hakkında", IV. Türk Tarih Kongresi 10-14 Kasım Ankara içinde (294-312), Ankara: Türk Tarih Kurumu.

WESTFALL, Richard S. (2004). Modern Bilimin Oluşumu, Ankara: TÜBİTAK.

YILDIRIM, Cemal. (2003). Bilim Tarihi. 8. bs. İstanbul: Remzi Kitabevi. 